\title{
Petrological and Geochemical Studies of Lepidolite (LCT Type) and Non-Lepidolite Pegmatite's from Chakrasila, Dhubri District, Assam, North East India
}

\author{
Rajkumar R. Meshram 1*, Bhupender Singh2, Mukesh Kumar Mishra3, H. Hrushikesh4, \\ Alam Siddiqui ${ }^{5}$, Devaseesh Shukla4, Rafique Akhtar ${ }^{4}$, Tushar M. Meshram1 \\ ${ }^{1}$ Regional Petrology Division, Geological Survey of India, CR, Nagpur, India \\ ${ }^{2}$ Geological Survey of India, State Unit: P\& H, NR, Chandigarh, India \\ ${ }^{3}$ Geological Survey of India, Western Region, Jaipur, India \\ ${ }^{4}$ Geological Survey of India, State Unit: Assam, NER, Guwahati, India \\ ${ }^{5}$ Geological Survey of India, Central Region, Bhopal, India \\ Email: *rajkumar_meshram@rediffmail.com, ${ }^{\star}$ rr.meshram@gsi.gov.in
}

How to cite this paper: Meshram, R.R., Singh, B., Mishra, M.K., Hrushikesh, H., Siddiqui, A., Shukla, D., Akhtar, R. and Meshram, T.M. (2021) Petrological and Geochemical Studies of Lepidolite (LCT Type) and Non-Lepidolite Pegmatite's from Chakrasila, Dhubri District, Assam, North East India. Open Journal of Geology, 11, 81-104. https://doi.org/10.4236/ojg.2021.113006

Received: January 21, 2021

Accepted: March 27, 2021

Published: March 30, 2021

Copyright $\odot 2021$ by author(s) and Scientific Research Publishing Inc. This work is licensed under the Creative Commons Attribution International License (CC BY 4.0).

http://creativecommons.org/licenses/by/4.0/ (c) (i) Open Access

\begin{abstract}
Lepidolite pegmatite occurs as intrusive within biotite gneiss and amphibolite of Assam Meghalaya Gneissic Complex (AMGC) or Precambrian Gneissic Complex in the Dhubri district, Assam. AMGC is the north western extension of the Proterozoic rocks of Meghalaya Plateau or Shillong plateau. In the field it occurs as small to large veins and scattered boulders. Lepidolite pegmatite is later intruded by non lepidolite pegmatite. Pegmatites are medium to coarse grained with quartz and K-feldspar. It also contains lepidolite, which occurs in the form of flakes and clusters varying from pink to purple in colour. Petrography of lepidolite pegmatite reveals lepidolite as major constituents with quartz, K-feldspar and muscovite as minor constituents. XRD analysis reveals lepidolite (muscovite) is major mineral phase with kaliophilite in minor amount. Geochemically, they are calc-alkaline to high calc-alkaline and per-aluminous in nature. On the basis of Alumina Saturation Index (ASI), these pegmatites resemble Lithium-Cesium-Tantalum (LCT) family and compositional affinity with S-type granites of orogenic environments. Trace element compositions ( $\mathrm{Rb}, \mathrm{Sr}, \mathrm{Ba}$ ) indicate crystal fractionations, variable degrees of fractionation, highly evolved nature of pegmatite's and strongly differentiated granites protoliths as source. The different tectonic discrimination diagrams indicate S-type and I-type melt for pegmatite derivations. Therefore, both the studied pegmatites could be an evolved variety of granitic rocks that originated from the same magma. The REE is relatively low to
\end{abstract}


moderate.

\section{Keywords}

Lepidolite, LCT, XRD, Per-Aluminous, Fractionations, AMGC and Shillong Plateau

\section{Introduction}

Pegmatites are coarse to very coarse-grained igneous rocks. Indeed, most pegmatites have granitic composition. Pegmatite hosts variety of minerals along with common minerals such as, lithium aluminosilicates (spodumene, petalite, lithium), tourmaline, garnets, beryl, pollucite; phosphates (monazite, amblygonite, lithiophyllite, topaz); oxides (cassiterite, columbite-tantalite, rutile, uranitite, zircon, corundum) [1]. Pegmatite contains elements such as $\mathrm{Li}, \mathrm{Rb}, \mathrm{Cs}, \mathrm{Be}, \mathrm{Ga}, \mathrm{Sc}, \mathrm{Y}$, REE, Sn, Nb, Ta, U, Th, Zr and Hf. Apart from these rare minerals, industrial minerals and gemstones are valuable in pegmatite [2]. Granite-pegma- tites are sources of rare metals and REEs (RMRE), which is commercially exploitable and economically viable [3]-[10].

Granitic pegmatites represent very unusual magmas, which constitute considerable reservoirs of rare elements [8] [9]. However, the genesis and mineralization of Li-Cs-Ta (LCT) pegmatites [11] are still being debated. Processes leading to the genesis of pegmatite are defined at two distinct geological scales: 1) a crustal scale where the pegmatite-forming melt is produced; and 2) the scale of the pegmatite body, where internal physico-chemical processes lead to localized concentrations of rare elements such as Li, Be, Cs, and Ta. Most LCT-type pegmatites are interpreted as the product of extreme granitic fractionation. Such a magmatic process is defined by fractional crystallization leading to an increase of rare elements and fluxes in the residual melt with increasing distance from the consolidating parental granitic source (see [1] [12] [13] [14], and references cited therein).

In India, pegmatites are of Precambrian age and occur in different geological domains [15] [16] [17] and contain rare metal ( $\mathrm{Sn}, \mathrm{Ta}, \mathrm{Be}$ and Li) bearing minerals, such as cassiterite, columbite, tantalite, beryl, lepidolite, amblygonite [18] [19] [20], pollucite [21]. These pegmatite belts are localised in metamorphic terrains and are genetically related to various granitic bodies [5] [22] [23] [24]. Micas are phyllosilicates with the simplified formula $\mathrm{IM}_{2-3} \square_{1-2} \mathrm{~T}_{4} \mathrm{O}_{10} \mathrm{~A}_{2}$, where I is commonly Cs, $\mathrm{K}, \mathrm{Na}, \mathrm{NH}_{4}, \mathrm{Rb}, \mathrm{Ba}, \mathrm{Ca} ; \mathrm{M}$ is usually $\mathrm{Li}, \mathrm{Fe}\left(\mathrm{Fe}^{3+}\right.$ or $\left.\mathrm{Fe}^{2+}\right), \mathrm{Mg}, \mathrm{Mn}$ $\left(\mathrm{Mn}^{3+}\right.$ or $\mathrm{Mn}^{2+)}, \mathrm{Zn}, \mathrm{Al}, \mathrm{Cr}, \mathrm{V}, \mathrm{Ti} \& \square$ represents a vacancy; $\mathrm{T}$ is usually $\mathrm{Be}, \mathrm{Al}, \mathrm{B}$, $\mathrm{Fe}^{3+}$, $\mathrm{Si}$, and $\mathrm{A}$ is usually $\mathrm{Cl}, \mathrm{F}, \mathrm{OH}, \mathrm{O}$ (oxy-micas), and $\mathrm{S}$ [25]. Lepidolite (or lithium mica) $\mathrm{K}(\mathrm{Li}, \mathrm{Al},[6] \square)_{3}(\mathrm{Si}, \mathrm{Al})_{4} \mathrm{O}_{10}(\mathrm{~F}, \mathrm{OH})_{2}$ is known for its pink and purple colours and is one of the major sources of the rare alkali metals rubidium and cesium. Ferromagnesian micas are significant mafic minerals in intermediate and basic igneous rocks whereas Li-bearing micas predominate in peralu- 
minous leucogranites, associated pegmatites and ore deposits [26]. Micas are useful as monitors of the physicochemical environment, in which they grew, as well as indicators of the metallogenetic potential of their host rock (e.g. [27] [28] [29] [30]). Li-bearing micas may be abundant in evolved late-stage granites, associated pegmatites, and ore deposits in metasomatic rocks [31] [32] [33] [34].

Lepidolite occurrence from the area was first reported by [35] and carried out detailed investigation and traced lepidolite bearing boulders over a $120 \mathrm{~m} \times 30$ $\mathrm{m}$ zone [36]. Subsequently, preliminary work carried out at Chakrasila and adjoining area through collection of geochemical samples and drilling [37] [38] [39]. The work for W, Sn \& REE in Ckakrasila area has been attended and indicated lepidolite occurrence in pegmatite with higher concentration of $\mathrm{Rb}$ and $\mathrm{Y}$ [40]. The purpose of this paper is geochemistry and genesis of lepidolite and non-lepidolite pegmatites.

\section{Geological Background}

The Assam Meghalaya Gneissic Complex (AMGC) is the north eastern extension of Indian Shield and is separated from the main mass of Peninsular India by Tertiary sediments of Ganges Brahmaputra and Cretaceous Rajmahal volcanics. The Shillong plateau composed of AMGC is considered as the detached portion of Eastern Ghats Mobile belt [41] or Chotanagpur Gneissic Complex [42] (Figure 1, after [43] [44]). The plateau is E-W striking horst block elevated about 600 $1800 \mathrm{~m}$ above the Bangladesh plains. The plateau comprises the NeoarcheanProterozoic to Early Paleozoic (2.6 - 0.5 Ga) basement gneissic rocks [45] [46] [47] [48] [49], the Paleo Mesoproterozoic NE-SW trending intracratonic Shillong basin constituting metasedimentary supracrustal rocks of the Shillong Group [45] [50] [51]. Shillong Group has undergone green schist facies of metamorphism [52]. Proterozoic-Early Paleozoic (881 - $479 \mathrm{Ma}$ ) equigranular to porphyritic coarse grained granite-granodiorites plutons (Mylliem granites and its equivalents) intruding the basement gneisses and the Shillong Group of rocks [49] [53]-[58]. Basic volcanics of Sylhet /Mikir traps of Cretaceous age occurs as concordant to discordant bodies within the Shillong group of rocks. The plateau is bounded and dissected by various fault systems E-W and N-S to the major earthquakes in the region. To North the plateau is bounded by Oldham fault [59] and to south it is flanked by Dauki fault [60] also considered as the extension of Son Narmada Fault. Advanced studies incorporated with chemical dating suggests that in the global scenario AMGC can be probably a leading edge during oblique collision between India with Austarlo Antartica during Pan-African final amalgamation and the Pan-African suture passing through Prydz Bay in Antarctica continued to the Shilling plateau which passes in between Sonapahar and Garo-Goalpara Hills regions of the Shillong plateau [48].

The study area is the part of Assam Meghalaya Gneissic Complex (AMGC)/ Precambrian Gneissic Complex in the Dhubri district, Assam. In Assam, the rocks of AMGC are the north western extension of the Proterozoic rocks of Meghalaya Plateau or Shillong plateau [59] [61]. The Precambrian rocks of AMGC 

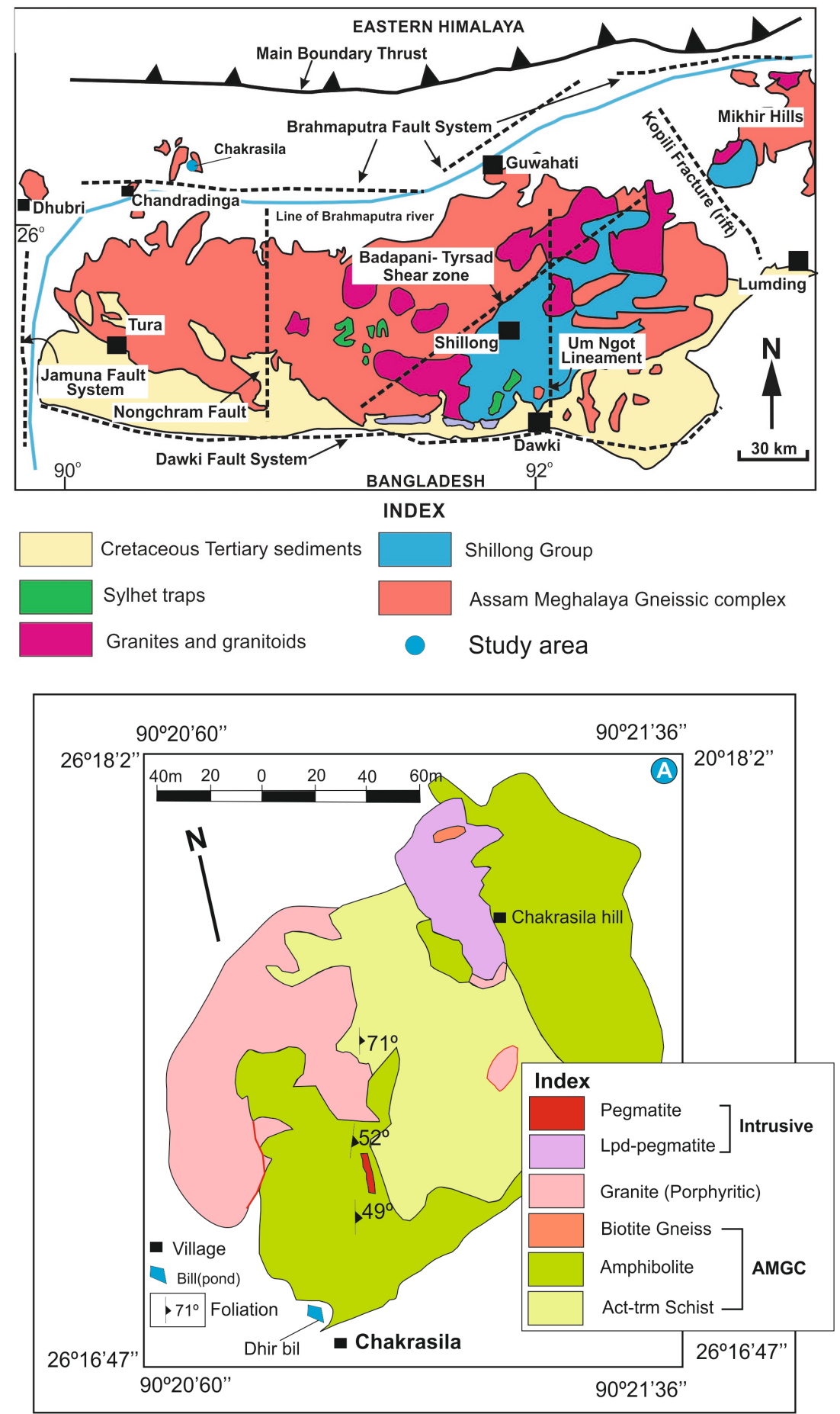

Figure 1. Regional geological map of Assam Megahlaya Gneissic Complex (AMGC) showing location of Chakrasila area (after, [43] [44]). (A) Geological map of Chakrasila area with lepidolite pegmatite [40].

are dominated by granulite to amphibolite facies of rocks interlayered with Banded Iron Formations (BIF), amphibolites, talc-actinolite schist and pyroxenites [40]. Gneissic complex occupies a large part of the central Assam and few isolated inselbergs cutting out of the Quaternary plains of western Brahmaputra 
Basins. The Gneissic Complex comprises of biotite-bearing quartzo-feld- spathic gneiss, schist, biotite-hornblende gneisses, migmatitic granitoid intruded by younger acidic (granite, aplite, pegmatite) and basic (metadolerite, epidiorite, amphibolite) intrusive rocks (Figure 1(A), after [40]).

\section{Field Occurrence and Petrography}

In the field, mineralogically pegmatites are composed of 1) quartz-feldspar; 2) quartz-feldspar-tourmaline-biotite-muscovite; 3) quartz-feldspar-biotite-muscovite and 4) quartz-feldspar-lepidolite. The detail work on lepidolite pegmatite and non-lepidolite pegmatite is discussed below.

\section{1) Lepidolite pegmatite:}

Lepidolite occurred as flakes within pegmatite veins, which is intruded in biotite gneiss and amphibolite in the northern tip of Dhir Bill (at Chakrasila). Amphibolite and actinolite tremolite schist are associated rocks in the area and are in the form of small bodies and boulders on Chakrasila hillock. In situ lepidolite/pegmatite veins as exposed in the area, only large blocks and boulders of lepidolite rocks scattered over the surface (Figure 2(A) and Figure 2(B)). The
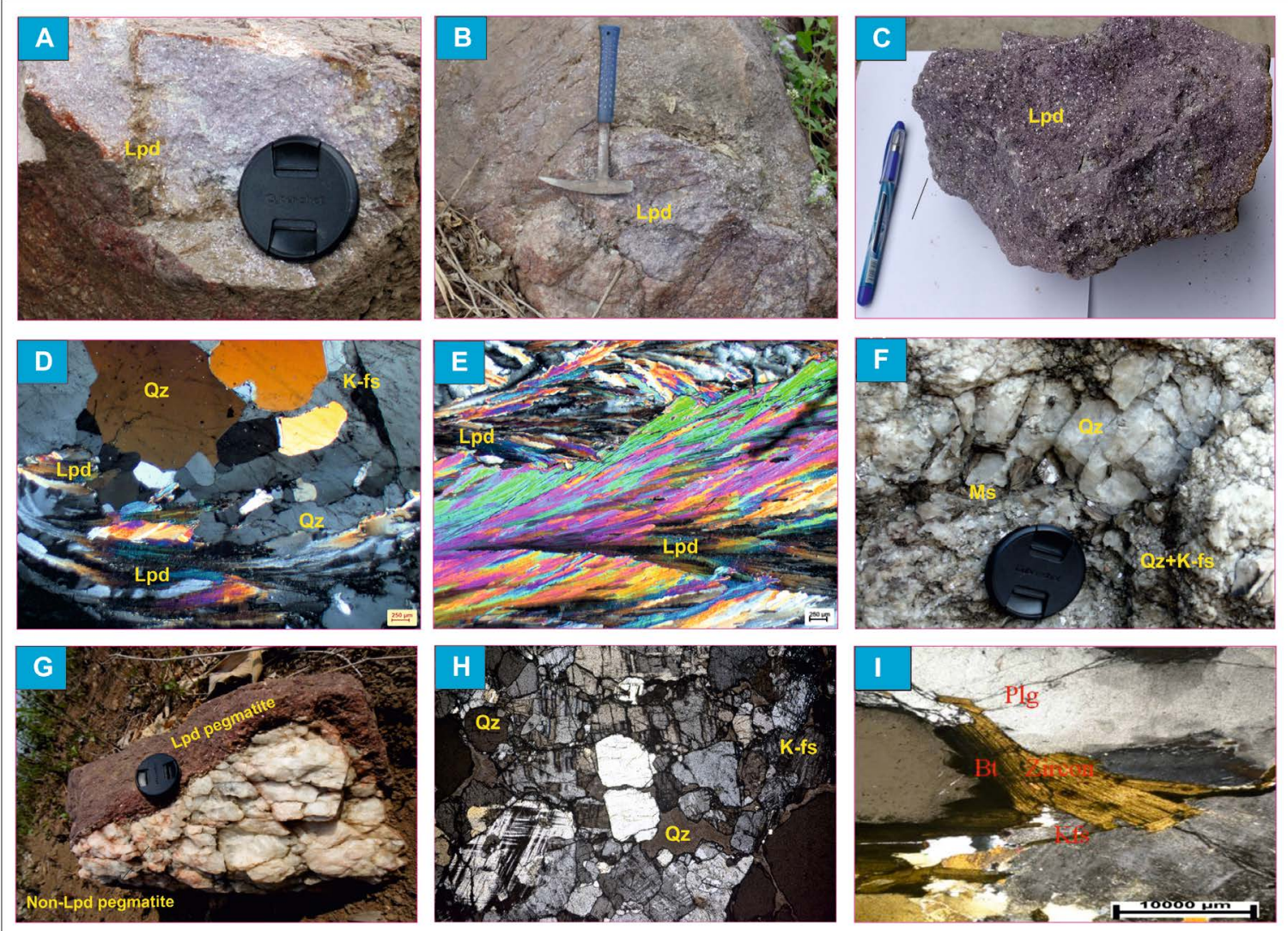

Figure 2. Field photographs of lepidolite pegmatite showing (A) pink lepidolite flakes, (B) small boulder with lepidolite flakes and fractures on surface, (C) Hand specimen of purple to violet lepidolite, (D) \& (E) Photomicrograph showing clusters of lepidolite showing fanning and deformation along with quartz. Field photographs of non-lepidolite pegmatite displaying (F) zoning with quartz core and fracturing, (G) Contact between lepidolite pegmatite and non-lepidolite pegmatite, $(\mathrm{H}) \&(\mathrm{I})$ Graphic intergrowth texture and zircon inclusion in biotite. 
large blocks and boulders of lepidolite bearing pegmatite spread over the surface for a length of $200 \mathrm{~m}$ with a width of $120-130 \mathrm{~m}$. It occurs in the form of fragmented boulder rather than continuous body/exposure. At places these boulders are traversed by quartz veins of $30-40 \mathrm{~cm}$ length and width of $2-4 \mathrm{~cm}$. The lepidolite predominantly pink to purplish-violet and in the form of fine to coarse flakes, radiating clusters with subordinate quartz, feldspar and muscovite (Figure $2(C))$. From the nature of concentration of blocks and boulders of lepidolite pegmatite over gently sloping ground it seems that they are in situ. Pegmatite is medium to coarse grained and is composed of lepidolite, quartz, alkali feldspar, muscovite and opaque minerals. It is massive, hard and compact.

In petrography, pegmatite is medium to coarse grained and is composed of lepidolite, quartz, alkali feldspar, muscovite and opaque minerals. Lepidolite is in the form of tabular to platy, laths to euhedral crystals, medium to coarse grained and is showing well developed parallel twinning (Figure 2(D)). It occurs in the form of phenocrysts and small grains as ground mass. The lepidolite is medium to fine grained and has layering in some parts and showing unidirectional cleavage and has equigranular structure. In some portion the rock is almost monomineralic in which lepidolite mineral varies from $90 \%$ to $95 \%$. It contains inclusion of quartz, which are mostly subhedral to anhedral while. Kfeldspar is subhedral and medium to fine grained (Figure 2(E)). In some parts, lepidolite flakes and clusters are deformed and showing kinking along with deformed quartz. Radiating crystals show fanning with wavy margins and deformed crystals reflects pinch and swelling along with ribbon shaped quartz.

\section{2) Non-lepidolite pegmatite:}

Non-lepidolite pegmatite (hereafter pegmatite) occurs as small to large veins and boulders. It ranges from 10 to $20 \mathrm{~m}$ in length and 20 to $50 \mathrm{~m}$ in width. Pegmatite is dominated in southern part and boulders of pegmatite also notice from hill top, central part, eastern and western flank of the mapped area. Pegmatite is coarse grained and composed of pink K-feldspar + quartz + biotite \pm muscovite \pm magnetite and garnet. It mainly NW-SE parallels to the foliation of the granite gneiss. This pegmatite is zoned (Figure 2(F)). The boarder part is comprised of $\mathrm{K}$-feldspar and muscovite on either side and coarse quartz crystals at the core part. It is also showing intrusive contact with lepidolite pegmatite (Figure $2(\mathrm{G})$ ).

In thin section, it is medium to coarse grained and consist of quartz, K-feldspar and plagioclase, biotite and muscovite (Figure $2(\mathrm{H})$ ). Garnet, zircon and opaque minerals occur as accessory mineral. The quartz grains are mostly subhedral to anhedral with deformation and shows wavy extinction and at places play undulose extinction. Biotite and muscovite is lath shaped and is present as very thin flakes (Figure 2(I)). Biotite is dark brown to dark yellowish and shows pleochroic halos surrounding the zircon grain (Figure 2(J)). K-feldspar is subhedral and more dominant over plagioclase-feldspar. At some places, microcline with cross hatched twinning is observed. Plagioclase feldspars occur as subhedral grains with polysynthetic twinning. Some overgrowth texture also noticed, K- 
feldspar growths over plagioclase-feldspar and shows perthite texture. Beside that plagioclase alters to sericite. In some places K-feldspar is replaced by plagioclase feldspar and muscovite.

\section{Sampling Methods and Analytical Techniques}

An area of 50 Sq.km. has been covered by large scale mapping on 1:10,000 and an area of 1 sq.km by detailed mapping on 1:5000 in and around Chakrasila hill. Samples from lepidolite bearing and non-lepidoilite pegmatites were collected systematically for petrological, mineralogical and geochemical studies. The thin section was prepared at Petrology Division, GSI, NER, Shillong and GSI, CR, Nagpur. The petrographic studies and photomicrographs of pegmatites was carried out at SU: Assam, NER, Guwahati using Nikon 600 Pol microscope with camera attachment and Leica DMRXP Pol microscope with Leica DMC 4500 camera and software attachment. Bulk pegmatite samples, collected from both the lepidolite bearing and non-lepidoilite pegmatites were analyzed for major, trace and REE by XRF and ICP-MS at Chemical Division, GSI, Shillong and Kolkata following standard analytical procedures. The X-ray diffraction phase analysis of lepidolite (separated flakes) has been carried out by using PANalytical XRD (EMPYREAN Diffractometer system) at mineral Physics Division, GSI, Central Region, Nagpur. The general conditions were $40 \mathrm{~mA}, 45 \mathrm{kV}$ at temperature of $25^{\circ} \mathrm{C}$ with $\mathrm{Cu}$ tube (anode material). Lepidolite is the major mineral phase in the form of muscovite (as lithium is not determined) and Kaliophilite in trace amount. The result of XRD analytical data is given in Table 1 and X-ray diffractograms in Figure 3.

\section{Geochemistry of the Pegmatites}

The whole-rock major- and trace-element compositions for pegmatites are presented in Table 2 and Table 3. The different geochemical variation and tectonic diagrams are plotted using these data.

1) Major oxide Geochemistry

In lepidolite pegmatite $\mathrm{SiO}_{2}$ is high ranging from 51.43 to $77.07 \mathrm{wt} \%$ (except one sample having $49.93 \mathrm{wt} \%$ might be due to contamination of mafic phase or error in sample collection). High $\mathrm{Al}_{2} \mathrm{O}_{3}$ varies from 12.13 to $28.65 \mathrm{wt} \%$, low to high $\mathrm{K}_{2} \mathrm{O}$ upto 8.99 wt\%, $\mathrm{Na}_{2} \mathrm{O}$ from 0.19 to 2.74 wt\%. Low amount of $\mathrm{CaO}$ ranging from 0.01 to $1.12 \mathrm{wt} \%$ (except one sample $10.82 \mathrm{wt} \%$ ) and $\mathrm{P}_{2} \mathrm{O}_{5}$ from 0.01 to $9.59 \mathrm{wt} \%$ (high in one sample). Low amount of $\mathrm{MnO}$ varying from 0.01 to $1.25 \mathrm{wt} \%, \mathrm{MgO}$ from 0.01 to1.91 $\mathrm{wt} \%$ (except $5.92 \% \mathrm{MgO}$ in one sample) and

Table 1. X-ray phase analytical result of lepidolite.

\begin{tabular}{ccc}
\hline Sample No. & Mineral phase & Remarks \\
\hline & Muscovite (lepidolite $)$ & Major \\
CS-1 & $(\mathrm{K}, \mathrm{Ba}, \mathrm{Na})_{0.75}(\mathrm{Al}, \mathrm{Mg}, \mathrm{Cr}, \mathrm{V})_{2}(\mathrm{Si}, \mathrm{Al}, \mathrm{V})_{4} \mathrm{O}_{10}(\mathrm{OH}, \mathrm{O})_{2}$ & \\
& Kaliophilite $\left(\mathrm{KAlSiO}_{4}\right)$ & Trace amount \\
\hline
\end{tabular}




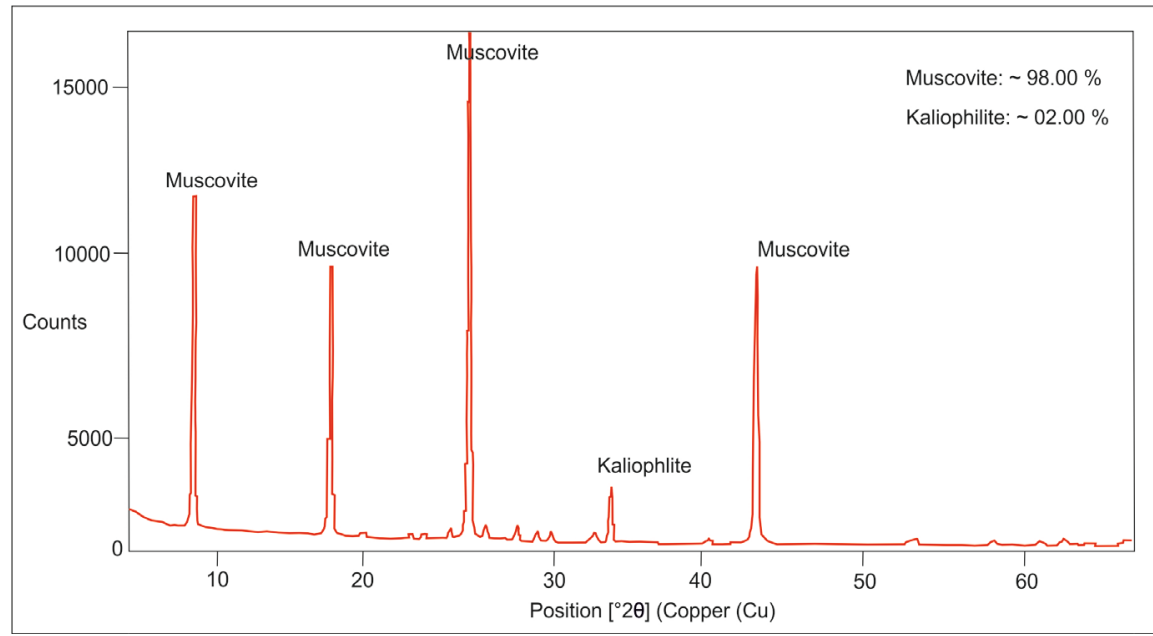

Figure 3. X-ray diffractogram of lepidolite.

Table 2. Major oxide data of lepidolite pegmatites (samples of L-series) and non-lepidolite pegmatite (samples of P-series).

\begin{tabular}{|c|c|c|c|c|c|c|c|c|c|c|c|c|c|}
\hline Sample & $\mathrm{SiO}_{2}$ & $\mathrm{TiO}_{2}$ & $\mathrm{Al}_{2} \mathrm{O}_{3}$ & $\mathrm{Fe}_{2} \mathrm{O}_{3}(\mathrm{~T})$ & $\mathrm{FeOT}$ & $\mathrm{MnO}$ & $\mathrm{MgO}$ & $\mathrm{CaO}$ & $\mathrm{Na}_{2} \mathrm{O}$ & $\mathrm{K}_{2} \mathrm{O}$ & $\mathrm{P}_{2} \mathrm{O}_{5}$ & LOI & Total \\
\hline $\mathrm{L}-1$ & 49.93 & 1 & 12.92 & 13.98 & 12.58 & 0.2 & 5.92 & 10.82 & 1.1 & 0.6 & 0.07 & 0.93 & 110.05 \\
\hline L-89 & 77.07 & 0.11 & 12.13 & 1.3 & 1.17 & 0.03 & 0.16 & 0.96 & 2.74 & 4.87 & 0.03 & 0.58 & 101.15 \\
\hline L-90 & 73.16 & 0.23 & 13.69 & 2.08 & 1.87 & 0.03 & 0.4 & 1.12 & 2.3 & 6.26 & 0.11 & 0.45 & 101.70 \\
\hline L-95 & 53.43 & 0.03 & 28.65 & 0.08 & 0.07 & 1.19 & 0.03 & 0.01 & 0.59 & 8.66 & 0.01 & 4.47 & 97.22 \\
\hline L-99 & 53.14 & 0.03 & 28.63 & 0.12 & 0.11 & 1.25 & 0.03 & 0.01 & 0.33 & 8.99 & 0.02 & 4.57 & 97.23 \\
\hline L-100 & 76.88 & 0.03 & 12.92 & 0.11 & 0.10 & 0.01 & 0.01 & 0.58 & 2.07 & 6.54 & 0.04 & 0.59 & 99.88 \\
\hline $\mathrm{L}-112$ & 51.43 & 0.76 & 25.03 & 9 & 8.10 & 0.05 & 1.91 & 0.03 & 0.34 & 6.77 & 0.02 & 4.6 & 108.04 \\
\hline Lep-1 & 51.93 & 0.03 & 29.01 & 0.08 & 0.07 & 0.26 & 0.25 & 0.01 & 0.19 & 0.01 & 9.59 & 3.99 & 95.42 \\
\hline P-7 & 71.87 & 0.2 & 12.85 & 1.81 & 1.63 & 0.03 & 0.39 & 1.27 & 2.94 & 4.84 & 0.12 & 0.79 & 98.74 \\
\hline P-8 & 70.82 & 0.23 & 13.55 & 2.32 & 2.09 & 0.03 & 0.51 & 1.5 & 2.57 & 4.87 & 0.06 & 0.87 & 99.42 \\
\hline P-20 & 71.56 & 0.27 & 12.8 & 3.09 & 2.78 & 0.05 & 0.53 & 1.62 & 2.31 & 5 & 0.08 & 0.72 & 100.81 \\
\hline P-32 & 74.4 & 0.14 & 12.11 & 1.55 & 1.39 & 0.03 & 0.23 & 1.04 & 2.81 & 4.53 & 0.03 & 0.45 & 98.71 \\
\hline P-51 & 75.79 & 0.17 & 12.29 & 1.7 & 1.53 & 0.03 & 0.33 & 1.48 & 2.8 & 4.34 & 0.09 & 0.41 & 100.96 \\
\hline P-39 & 74.46 & 0.15 & 12.76 & 1.7 & 1.53 & 0.03 & 0.22 & 1.17 & 2.7 & 5.42 & 0.09 & 0.45 & 100.68 \\
\hline P-110 & 77.71 & 0.04 & 12.41 & 0.35 & 0.31 & 0.01 & 0.08 & 1.64 & 3.03 & 3.28 & 0.03 & 0.69 & 99.58 \\
\hline P-113 & 98.72 & 0.02 & 0.01 & 0.14 & 0.13 & 0.01 & 0.01 & 0.01 & 0.01 & 0.01 & 0.01 & 0.29 & 99.37 \\
\hline P-209 & 78.64 & 0.22 & 9.89 & 2.97 & 2.67 & 0.02 & 0.01 & 0.36 & 1.8 & 5.31 & 0.03 & 0.39 & 102.31 \\
\hline $\mathrm{P}-230$ & 71.7 & 0.05 & 17.04 & 0.84 & 0.76 & 0.04 & 0.12 & 1.06 & 3.34 & 4.06 & 0.02 & 0.67 & 99.70 \\
\hline P-238 & 71.45 & 0.04 & 16.27 & 0.25 & 0.22 & 0.01 & 0.02 & 4.58 & 5.23 & 0.35 & 0.06 & 0.59 & 99.07 \\
\hline P-5 & 74.43 & 0.03 & 13.23 & 0.22 & 0.20 & 0.01 & 0.02 & 0.11 & 1.74 & 0.03 & 7.45 & 0.49 & 97.96 \\
\hline P-9 & 68.45 & 0.03 & 16.93 & 0.17 & 0.15 & 0.01 & 0.02 & 0.15 & 2.24 & 0.03 & 10.26 & 0.99 & 99.43 \\
\hline P-11 & 73.22 & 0.05 & 14.24 & 0.34 & 0.31 & 0.01 & 0.1 & 0.13 & 1.5 & 0.02 & 9.35 & 0.32 & 99.59 \\
\hline P-12 & 77.87 & 0.05 & 12.43 & 0.35 & 0.31 & 0.01 & 0.08 & 1.6 & 2.9 & 0.03 & 3.23 & 0.65 & 99.51 \\
\hline P-25 & 68.7 & 0.03 & 16.69 & 0.17 & 0.15 & 0.01 & 0.01 & 0.08 & 1.12 & 12.37 & 0.03 & 0.29 & 99.65 \\
\hline
\end{tabular}




\section{Continued}

\begin{tabular}{|c|c|c|c|c|c|c|}
\hline Sample & $\begin{array}{c}\mathrm{ASI}=\mathrm{Al}_{2} \mathrm{O}_{3} /(\mathrm{CaO}+ \\
\mathrm{Na}_{2} \mathrm{O}+\mathrm{K}_{2} \mathrm{O}\end{array}$ & $\mathrm{Al}_{2} \mathrm{O}_{3} /\left(\mathrm{Na}_{2} \mathrm{O}+\mathrm{K}_{2} \mathrm{O}\right)$ & $\mathrm{CaO} /\left(\mathrm{Na}_{2} \mathrm{O}+\mathrm{K}_{2} \mathrm{O}\right)$ & $\mathrm{FeO} /(\mathrm{Feo}+\mathrm{MgO})$ & $\mathrm{Na}_{2} \mathrm{O}+\mathrm{K}_{2} \mathrm{O}-\mathrm{CaO}$ & $\begin{array}{c}\mathrm{HI}=\mathrm{CaO}+\mathrm{MgO}+ \\
\mathrm{FeOT}\end{array}$ \\
\hline L-1 & 1.032 & 7.6 & 6.36 & 0.68 & -9.12 & 29.32 \\
\hline L-89 & 1.415 & 1.59 & 0.13 & 0.88 & 6.65 & 2.29 \\
\hline L-90 & 1.414 & 1.60 & 0.13 & 0.82 & 7.44 & 3.39 \\
\hline L-95 & 3.094 & 3.10 & 0.00 & 0.71 & 9.24 & 0.11 \\
\hline L-99 & 3.069 & 3.07 & 0.00 & 0.78 & 9.31 & 0.15 \\
\hline L-100 & 1.406 & 1.50 & 0.07 & 0.91 & 8.03 & 0.69 \\
\hline L-112 & 3.506 & 3.52 & 0.00 & 0.81 & 7.08 & 10.04 \\
\hline Lep-1 & 138.143 & 145.05 & 0.05 & 0.22 & 0.19 & 0.33 \\
\hline P-7 & 1.420 & 1.65 & 0.16 & 0.81 & 6.51 & 3.29 \\
\hline$P-8$ & 1.516 & 1.82 & 0.20 & 0.80 & 5.94 & 4.10 \\
\hline$P-20$ & 1.433 & 1.75 & 0.22 & 0.84 & 5.69 & 4.93 \\
\hline P-32 & 1.445 & 1.65 & 0.14 & 0.86 & 6.3 & 2.66 \\
\hline P-51 & 1.426 & 1.72 & 0.21 & 0.82 & 5.66 & 3.34 \\
\hline P-39 & 1.374 & 1.57 & 0.14 & 0.87 & 6.95 & 2.92 \\
\hline P-110 & 1.561 & 1.97 & 0.26 & 0.80 & 4.67 & 2.03 \\
\hline P-113 & 0.333 & 0.5 & 0.5 & 0.93 & 0.01 & 0.15 \\
\hline P-209 & 1.324 & 1.39 & 0.05 & 1.00 & 6.75 & 3.04 \\
\hline P-230 & 2.014 & 2.30 & 0.14 & 0.86 & 6.34 & 1.94 \\
\hline P-238 & 1.601 & 2.92 & 0.82 & 0.92 & 1 & 4.82 \\
\hline P-5 & 7.037 & 7.47 & 0.06 & 0.91 & 1.66 & 0.33 \\
\hline P-9 & 6.996 & 7.46 & 0.07 & 0.88 & 2.12 & 0.32 \\
\hline P-11 & 8.630 & 9.37 & 0.09 & 0.75 & 1.39 & 0.54 \\
\hline P-12 & 2.744 & 4.24 & 0.55 & 0.80 & 1.33 & 1.99 \\
\hline P-25 & 1.230 & 1.24 & 0.01 & 0.94 & 13.41 & 0.24 \\
\hline
\end{tabular}

Table 3. Trace element data of lepidolite pegmatites (samples of L-series) and non-lepidolite pegmatite (samples of P-series).

\begin{tabular}{|c|c|c|c|c|c|c|c|c|c|c|c|c|c|c|c|c|c|c|c|c|c|c|c|c|}
\hline Sample & $\mathrm{Ba}$ & Co & $\mathrm{Cr}$ & $\mathrm{Cu}$ & $\mathrm{Ga}$ & $\mathrm{Nb}$ & $\mathrm{Ni}$ & $\mathrm{Pb}$ & $\mathbf{R b}$ & $\mathrm{Sc}$ & $\mathrm{Sr}$ & Th & $\mathrm{V}$ & $\mathrm{Y}$ & $\mathrm{Zn}$ & $\mathrm{Zr}$ & Sn & Hf & $\mathrm{Ta}$ & Mo & w & $\mathrm{Ge}$ & $\mathrm{Be}$ & $\mathrm{U}$ \\
\hline L-1 & 140 & 73 & 140 & 59 & 26 & 5 & 87 & 3 & 22 & 76 & 125 & 11 & 444 & 22 & 143 & 70 & 337.51 & 2.32 & 286.89 & 0.50 & 14.94 & 3.89 & 18.46 & 11.74 \\
\hline L-89 & 150 & 1 & 15 & 2 & 28 & 16 & 2 & 57 & 345 & 5 & 32 & 33 & 20 & 60 & 40 & 73 & 9.68 & 4.96 & 3.92 & 0.50 & 7.52 & 2.44 & 1.80 & 1.99 \\
\hline L-90 & 821 & 6 & 22 & 6 & 25 & 6 & 2 & 59 & 281 & 5 & 109 & 102 & 20 & 26 & 55 & 259 & 1.51 & 0.82 & 1.20 & 0.50 & 1.08 & 2.28 & 1.16 & 0.50 \\
\hline L-95 & 50 & 5 & 15 & 1 & 162 & 58 & 25 & 37 & 12,409 & 3.5 & 6 & 4 & 20 & 759 & 602 & 15 & 1.99 & 1.15 & 1.88 & 0.50 & 2.07 & 2.57 & 1.82 & 0.61 \\
\hline L-99 & 50 & 1 & 15 & 1 & 163 & 54 & 23 & 29 & 13138 & 3.5 & 6 & 4 & 20 & 802 & 676 & 15 & 7.97 & 10.85 & 2.63 & 0.50 & 6.28 & 3.61 & 1.07 & 2.37 \\
\hline L-100 & 622 & 3 & 15 & 8 & 21 & 5 & 2 & 93 & 239 & 5 & 130 & 11 & 20 & 87 & 10 & 98 & 5.19 & 27.60 & 1.05 & 0.50 & 1.98 & 2.70 & 1.86 & 3.10 \\
\hline L-112 & 575 & 16 & 100 & 63 & 42 & 21 & 19 & 45 & 393 & 26 & 23 & 24 & 118 & 21 & 138 & 126 & 9.12 & 5.30 & 43.63 & 0.50 & 4.73 & 3.57 & 47.22 & 4.31 \\
\hline Lep-1 & 50 & 1 & 15 & 1 & 157 & 83 & 24 & 35 & 15,337 & 8 & 6 & 4 & 20 & 939 & 51 & 15 & 312.85 & 6.51 & 269.86 & 0.50 & 14.59 & 3.59 & 17.45 & 11.26 \\
\hline P-7 & 503 & 5 & 23 & 6 & 29 & 13 & 2 & 54 & 302 & 4 & 116 & 4 & 20 & 62 & 49 & 130 & 15.73 & 20.56 & 3.67 & 1.02 & 2.73 & 6.30 & 5.30 & 10.09 \\
\hline
\end{tabular}




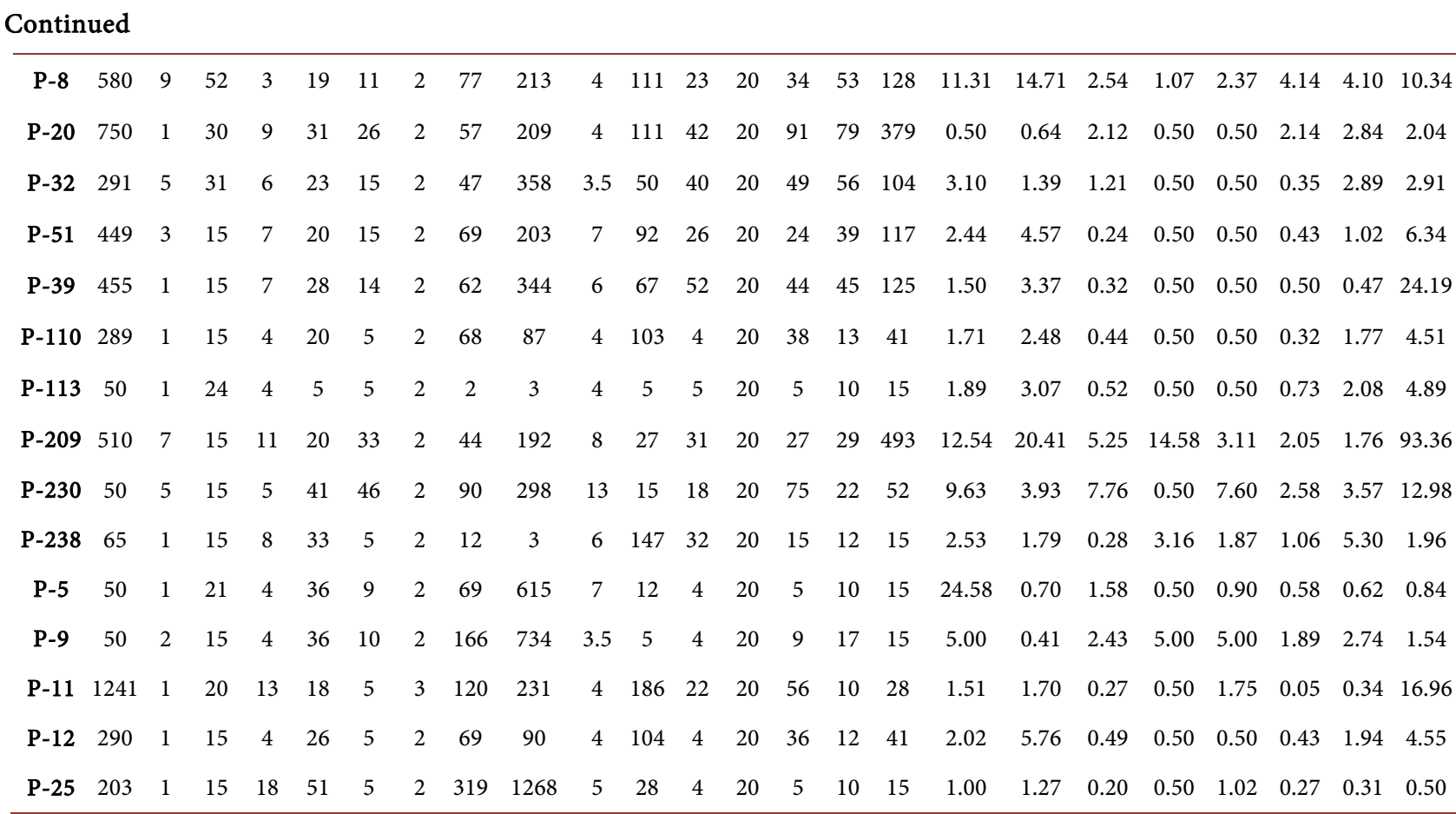

$\mathrm{TiO}_{2}$ is varying from 0.03 to $0.76 \mathrm{wt} \% . \mathrm{Fe}_{2} \mathrm{O}_{3 \mathrm{~T}}$ is varying from 0.08 to $9 \mathrm{wt} \%$ and one sample have high amount $13.98 \mathrm{wt} \%$.

Pegmatite shows high amount of $\mathrm{SiO}_{2}$ ranging from 68.45 to $78.64 \mathrm{wt} \%$ (except one sample having $98.72 \mathrm{wt} \%$ quartz rich sample). High $\mathrm{Al}_{2} \mathrm{O}_{3}$ varies from 9.89 to 17.04 wt\%, high $\mathrm{K}_{2} \mathrm{O}$ upto $12.37 \mathrm{wt} \%$ and high $\mathrm{Na}_{2} \mathrm{O}$ from 1.12 to 5.23 wt\%. Low $\mathrm{CaO}$ ranging from 0.08 to $4.58 \mathrm{wt} \%$ (except one sample $10.82 \mathrm{wt} \%$ ) and $\mathrm{P}_{2} \mathrm{O}_{5}$ from 0.01 to $10.56 \mathrm{wt} \%$. Low $\mathrm{MnO}$ and $\mathrm{MgO}$ vary from 0.01 to 0.05 wt \% and 0.01 to $0.53 \mathrm{wt} \%$ respectively. $\mathrm{Fe}_{2} \mathrm{O}_{3 \mathrm{~T}}$ is varying from 0.14 to $3.09 \mathrm{wt} \%$.

These high amounts of major elements such as $\mathrm{SiO}_{2}, \mathrm{Al}_{2} \mathrm{O}_{3}, \mathrm{~K}_{2} \mathrm{O}$ and $\mathrm{Na}_{2} \mathrm{O}$ with low amount of $\mathrm{CaO}, \mathrm{MnO}, \mathrm{MgO}$ and $\mathrm{TiO}_{2}$ are indicative of the importance of fractional crystallization in their petrogenesis. Fairly high amount of $\mathrm{P}_{2} \mathrm{O}_{5}$ and $\mathrm{Fe}_{2} \mathrm{O}_{3 \mathrm{~T}}$ could be related to crystallization of minerals, such as apatite, titanite, and biotite from magma in early stages of its evolution.

\section{a) Classification of pegmatites:}

On $\mathrm{SiO}_{2}$ vs $\mathrm{Na}_{2} \mathrm{O}+\mathrm{K}_{2} \mathrm{O}$ TAS diagram of [62], the compositions of samples plotted closed to the field of alkali granite and granite with sub-alkaline to alkaline nature (Figure 4(A)). The $\mathrm{SiO}_{2}$ vs $\mathrm{K}_{2} \mathrm{O}$ binary diagram (after, [63]) indicates calc-alkaline to high calc-alkaline characters for majority samples. Whereas, some samples plotted in tholeiitic field and few lepidolite samples in soshonitic field (Figure 4(B)). The molar $\mathrm{Al}_{2} \mathrm{O}_{3} /\left(\mathrm{CaO}+\mathrm{Na}_{2} \mathrm{O}+\mathrm{K}_{2} \mathrm{O}\right)$ versus molar $\mathrm{Al}_{2} \mathrm{O}_{3} /$ $\left(\mathrm{Na}_{2} \mathrm{O}+\mathrm{K}_{2} \mathrm{O}\right)(\mathrm{A} / \mathrm{CNK}$ vs $\mathrm{A} / \mathrm{NK})$ diagram [64] [65] reflect the per-aluminous character of both the pegmatites (Figure $4(\mathrm{C})$ ). In $\mathrm{SiO}_{2}$ vs $\mathrm{Na}_{2} \mathrm{O}+\mathrm{K}_{2} \mathrm{O}-\mathrm{CaO}$ (MALI) diagram of [66] samples plot in the field of calcic and calc-alkalic field. The overlapping field of I-type, A-type and S-type are from [67], where studied samples indicate both S-type and I-type magmatic characters (Figure 4(D)). 
Reference [68] have proposed a new classification scheme to separate calc-alkaline granites from A-type granites and oxidised A-type granites from reduced A-type granites. In the $\mathrm{CaO} /\left(\mathrm{FeOt}+\mathrm{MgO}+\mathrm{TiO}_{2}\right)$ vs. $\mathrm{CaO}+\mathrm{Al}_{2} \mathrm{O}_{3}$ and $\mathrm{CaO} /(\mathrm{FeOt}+$ $\mathrm{MgO}+\mathrm{TiO}_{2}$ ) vs. $\mathrm{Al}_{2} \mathrm{O}_{3}$ diagrams (Figure 4(E) and Figure 4(F)), the data falls in the A-type, calc-alkaline granite fields and some samples away from the calc-alkaline field. In the $\mathrm{FeOt} /(\mathrm{FeOt}+\mathrm{MgO})$ vs. $\mathrm{Al}_{2} \mathrm{O}_{3}$ and $\mathrm{FeOt} /(\mathrm{FeOt}+\mathrm{MgO})$ vs. $\mathrm{Al}_{2} \mathrm{O}_{3} /\left(\mathrm{K}_{2} \mathrm{O} / \mathrm{Na}_{2} \mathrm{O}\right)$ diagrams (Figure $4(\mathrm{G})$ and Figure $4(\mathrm{H})$ ), most of the samples plot near to oxidised A-type field and some towards the reduced A-type field. Few samples fall in the field of calc-alkaline granite field.

On the basis of Alumina Saturation Index (ASI), these pegmatites resemble Lithium-Cesium-Tantalum (LCT) family of pegmatites (e.g., [1] [2]). Their A/NK values are in the range of 1.50 - 3.52 (except two samples having $7.6 \&$ 145.05) for lepidolite pegmatite. However, non-lepidolite pegmatite has values
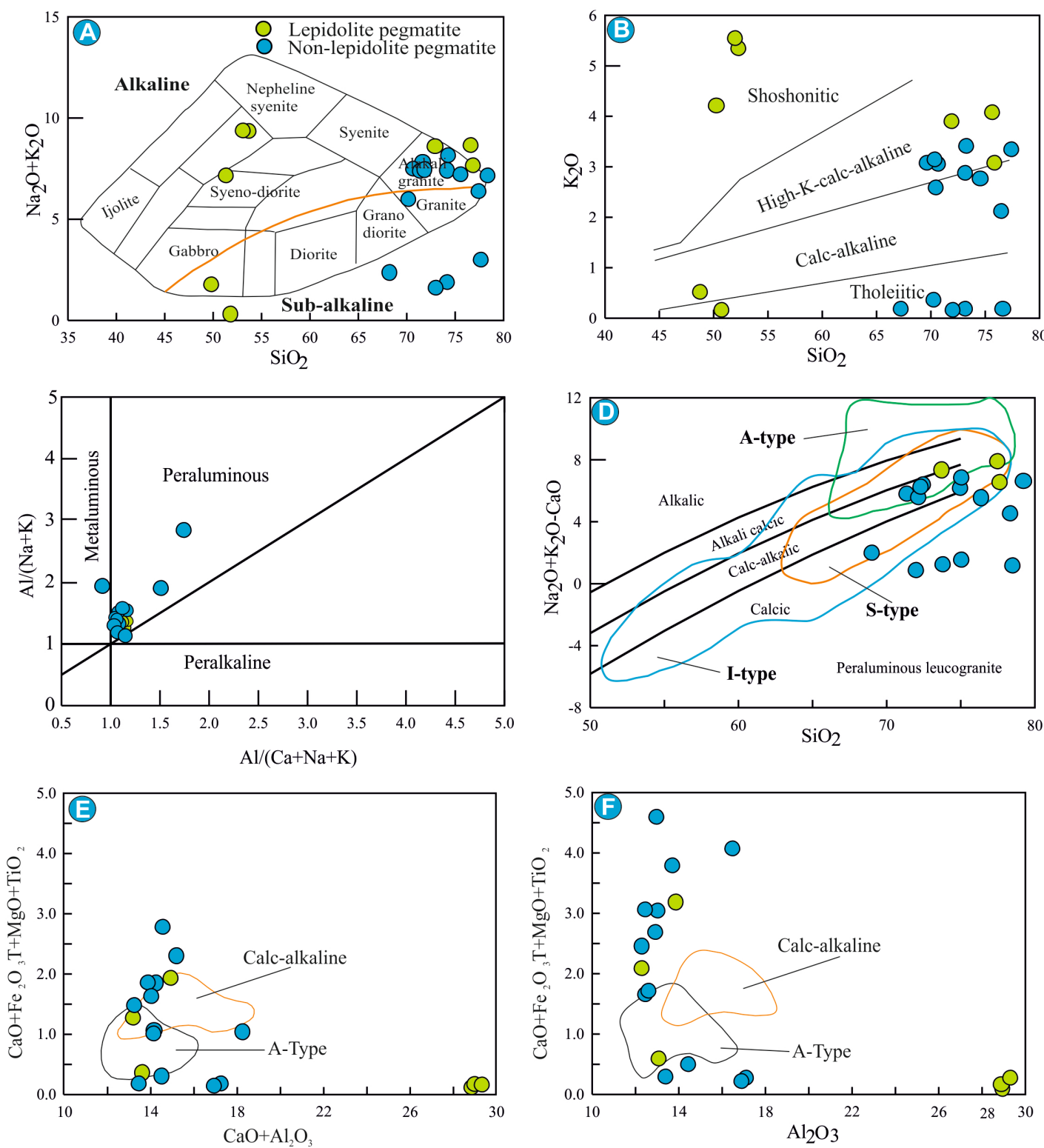

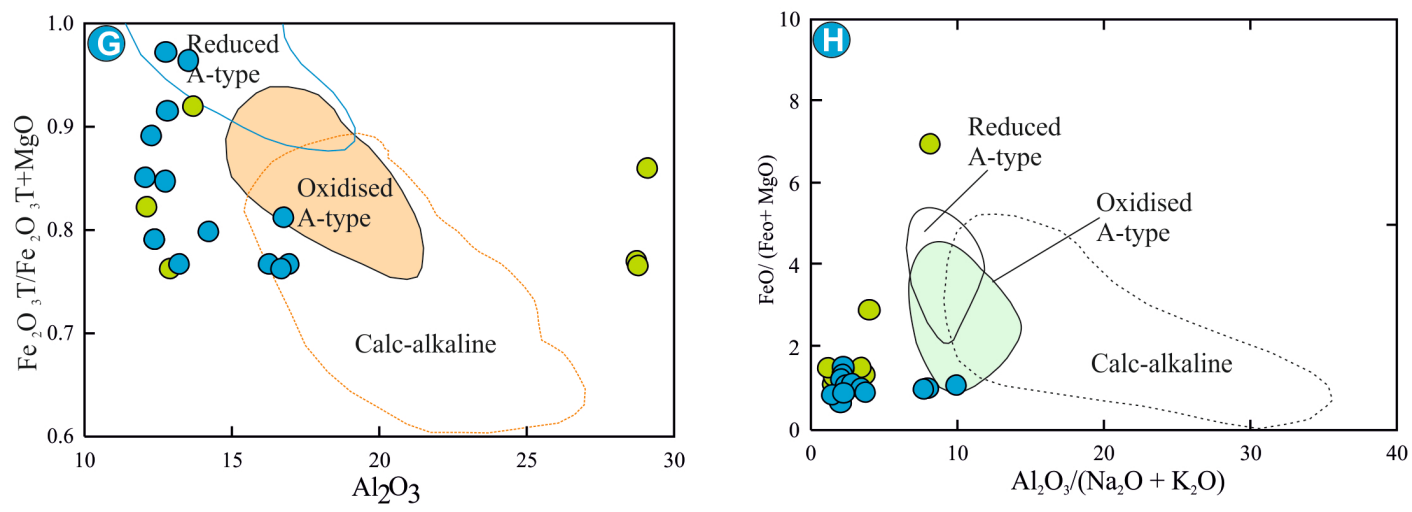

Figure 4. Geochemical diagrams displaying (A) $\mathrm{SiO}_{2}$ vs $\mathrm{Na}_{2} \mathrm{O}+\mathrm{K}_{2} \mathrm{O}$ TAS classification diagram of pegmatites. Both the pegmatite's indicates alkali granite to granite affinity (after, [62]), (B) The $\mathrm{SiO}_{2} \mathrm{vs}_{2} \mathrm{O}$ binary diagram indicates calc-alkaline to high calc-alkaline characters (after, [87]). Some non-lepidolite pegmatite samples indicate tholeiitic field and three samples of lepidolite pegmatite plot in the shoshonitic field, (C) $\mathrm{A} / \mathrm{CNK}$ vs A/NK diagram reflects the per-aluminous character of both the pegmatite's [64] [65], (D) In $\mathrm{SiO}_{2}$ vs $\mathrm{Na}_{2} \mathrm{O}+\mathrm{K}_{2} \mathrm{O}-\mathrm{CaO}$ diagram of [66], samples plot in the field of calcic to alkali-calcic field for both the pegmatites. The field of I-type, A-type and S-type are from [67], (E) \& (F) In the $\mathrm{CaO} /\left(\mathrm{FeOt}+\mathrm{MgO}+\mathrm{TiO}_{2}\right) \mathrm{vs}$. $\mathrm{CaO}+\mathrm{Al}_{2} \mathrm{O}_{3}$ and $\mathrm{CaO} /\left(\mathrm{FeOt}+\mathrm{MgO}+\mathrm{TiO}_{2}\right)$ vs. $\mathrm{Al}_{2} \mathrm{O}_{3}$ diagrams the data falls in the A-type, calc-alkaline granite fields and some samples away from the calc-alkaline field (after, [68]), (G) \& (H) In the FeOt/(FeOt + $\mathrm{MgO})$ vs. $\mathrm{Al}_{2} \mathrm{O}_{3}$ and $\mathrm{FeOt} /(\mathrm{FeOt}+\mathrm{MgO})$ vs. $\mathrm{Al}_{2} \mathrm{O}_{3} /\left(\mathrm{K}_{2} \mathrm{O} / \mathrm{Na}_{2} \mathrm{O}\right)$ diagrams, most of the samples plot near to oxidised A-type field and some towards the reduced A-type field and differing from calc-alkaline field. However, clustering of samples is also witnessed near to oxidised A-type field (after, [68]).

ranges from of 0.50 - 9.37. The $\mathrm{A} / \mathrm{CNK}$ values are in the range of $1.406-3.506$ (except two samples have $1.032 \& 138.143$ ) for lepidolite pegmatite. The non-lepidolite pegmatite has $\mathrm{A} / \mathrm{CNK}$ values are in the range of $0.333-8.630$. Most pegmatites with the LCT signature have compositional affinity with S-type granites [69]. These types of pegmatites are usually related to S-type granites of orogenic environments (i.e., subduction zones or continental collision zones) [2] [11] [70] [71] [72].

\section{2) Trace and immobile element geochemistry}

In lepidolite pegmatite, trace element Ba varies from 50 to $821 \mathrm{ppm}, \mathrm{Ga}$ from 26 to $163 \mathrm{ppm}$ and $\mathrm{Rb}$ from 239 to $393 \mathrm{ppm}$ (three samples have 12,409, 13,138 \& 15,537 ppm Rb content). Sr from 6 to $130 \mathrm{ppm}$, Y ranging from 21 to 939 $\mathrm{ppm}, \mathrm{Zn}$ from 10 to $676 \mathrm{ppm}$. In non lepidolite pegmatite, trace element Ba varies from 50 to $1241 \mathrm{ppm}, \mathrm{Ga}$ from 5 to $41 \mathrm{ppm}$ and $\mathrm{Rb}$ from 3 to $1268 \mathrm{ppm}$. Sr from 5 to $186 \mathrm{ppm}$, $\mathrm{Y}$ ranging from 5 to $91 \mathrm{ppm}, \mathrm{Pb}$ from 12 to $319 \mathrm{ppm}$.

\section{a) Tectonic discriminations and fractional crystallization:}

Trace element compositions of the studied rocks are presented, briefly. An increase in the amounts of $\mathrm{Rb}$ can be correlated with late stage crystallization of $\mathrm{K}$-feldspar and biotite, and decrease in Sr contents can be due to fractional crystallization of plagioclase. Barium content is commonly used as indicator of the evolution in granites and pegmatites, which decreases with increasing crystal fractionation [73] [74], and the decrease in content of $\mathrm{Ba}$ is marked. High amount of $\mathrm{Ba}(50-821 \mathrm{ppm})$ is due to the presence of minerals, such as K-feldspar and biotite. Rubidium contents in the pegmatites vary from 239 to 
$393 \mathrm{ppm}$ and Sr contents from 6 to $130 \mathrm{ppm}$. With increasing concentrations of $\mathrm{K}$, the $\mathrm{Rb}$ contents of the rocks increase, as well. The increasing concentration of $\mathrm{Ba}, \mathrm{Sr}$ and $\mathrm{Cs}$ values, are also observed in samples due to their similar geochemical behavior. These chemical characteristics indicate that the studied pegmatites are highly evolved varieties of granitoids of the region. As a rare alkali metal $\mathrm{Rb}$ is enriched in K-bearing minerals during progress of pegmatite crystallization [73], the ratio of $\mathrm{K} / \mathrm{Rb}$ is indicative of the general fractionation.

A hybridization index of $\mathrm{CaO}+\mathrm{MgO}+\mathrm{FeO}_{\mathrm{T}}$ is useful in quantifying deviations from leucogranitic melt compositions (see [75]). $\mathrm{Rb}$ vs. $\mathrm{Sr}$ and $\mathrm{Rb}$ vs. $\mathrm{Ba}$ plots showing variable degrees of fractionation within the simple-type and hybridized pegmatites and granites; the trend for normal granites is plotted for comparison. The pegmatites are strongly to moderately evolved, as demonstrated by $\mathrm{Rb}-\mathrm{Ba}-\mathrm{Sr}$ trends that vary between signatures of a normal and a moderately fractionated granitic pegmatite [76]. The majority of the pegmatites plots away the normal granite trend. Ratios of $\mathrm{K} / \mathrm{Rb}$ vs. Cs (see [73]) are good proxies to evaluate the $\mathrm{K}-\mathrm{Rb}$ and $\mathrm{K}-\mathrm{Cs}$ substitution in potassium feldspar and micas within the bulk samples. The granites differ from the granitic pegmatites by having significantly lower $\mathrm{Rb}$, but comparable Cs contents. The studied samples follow a simple type pegmatite fractionation pathway on the $\mathrm{K}_{2} \mathrm{O} / \mathrm{Rb}$ vs. $\mathrm{Rb}$ plots. The trends are very steep, increasing sharply in $\mathrm{Rb}$. The pegmatites clearly lie on a deeper $\mathrm{K}_{2} \mathrm{O} / \mathrm{Rb}$ vs. $\mathrm{Rb}$ path.

b) The pegmatite protoliths (source rock) characteristics:

A few samples contain progressively less $\mathrm{Sr}$ and $\mathrm{Ba}$ and more $\mathrm{Rb}$ as a result of fractionation. High amounts of $\mathrm{Rb}$ in the studied pegmatites, indicate that these samples are placed in the category of strongly differentiated granites in the ternary Rb-Ba-Sr plot [76]. Other samples are moderately evolved chemically. On the basis of diagram from [77] studied pegmatites plot mainly in S-type granites fields and few samples plot in I-type field indicate involvement S-type granite as major source along with I-type granite as minor constituents. Therefore, both the studied pegmatites could be an evolved variety of granitic rocks that originated from the same magma.

The $\mathrm{Rb}$ vs $\mathrm{Sr}$ and $\mathrm{Rb}$ vs $\mathrm{Ba}(\mathrm{ppm})$ diagrams showing variable degrees of fractionation, the studied samples plotted above the normal granite field (Figure 5(A) and Figure 5(B)). The trend of normal granite field is after [76]. Three samples have more than $10,000 \mathrm{ppm} \mathrm{Rb}$ and not plotted in the diagram, which indicate more fractionation of $\mathrm{Rb}, \mathrm{Sr}$ and $\mathrm{Ba}$ in both the pegmatites. $\mathrm{Rb}$ vs $\mathrm{K}_{2} \mathrm{O} / \mathrm{Rb}$ (ppm) diagram (after, [78]) evaluate the $\mathrm{K}-\mathrm{Rb}$ fractionation in simpletype and complex-type (hybridized) pegmatites. The analysed data plot near the arrow of simple type pegmatite and few samples scattered around hybrid pegmatite (Figure 5(C)). The trace element $\mathrm{Zr}$ vs $\mathrm{TiO}_{2}$ diagram [79] indicate mainly S-type granitic source for both the pegmatites and few samples of plots in I-type field (Figure 5(D)). In triangular $\mathrm{CaO}-\mathrm{Al}_{2} \mathrm{O}_{3}-\mathrm{Na}_{2} \mathrm{O}-\mathrm{K}_{2} \mathrm{O}-\mathrm{Fe}_{2} \mathrm{O}_{3 \mathrm{~T}}+\mathrm{MgO}$ diagram (after, [77]) indicate mainly S-type field and I-type field for some samples (Figure 5(E)) and $\mathrm{Zr}$ vs $\mathrm{Nb} / \mathrm{Ta}(\mathrm{ppm})$ diagram (after, [78]) indicate enrichment 
and fractionation of $\mathrm{Nb}$ (Figure $5(\mathrm{~F})$ ). The $\mathrm{Nb} / \mathrm{Ta}$ ratios for pegmatites range between 0.31 and 30.93 in lepidolite pegmatite and between 4.11 and 61.98. $\mathrm{Nb} / \mathrm{Ta}$ vs. $\mathrm{Ta}$ and $\mathrm{Nb} / \mathrm{Ta}$ vs. $\mathrm{K}_{2} \mathrm{O} / \mathrm{Rb}$ plots show variations in $\mathrm{Nb} / \mathrm{Ta}$ indicate fractionation between simple-type pegmatites vs. hybridized pegmatites; the arrows indicate the direction of a more evolved (i.e. fractionated) melt undergoing hybridization. In $\mathrm{Nb} / \mathrm{Ta}$ vs Ta samples plot in lower end of hybridization arrow and few towards the arrow head (Figure $5(\mathrm{G})$ ) and $\mathrm{Nb} / \mathrm{Ta}$ vs $\mathrm{K}_{2} \mathrm{O} / \mathrm{Rb}$ diagram samples plot around hybridization arrow indicate more fractionation of $\mathrm{Ta}$ and $\mathrm{Rb}$ in lepidolite pegmatite (Figure $5(\mathrm{H})$ ). Variations in $\mathrm{Nb} / \mathrm{Ta}$ and $\mathrm{Zr} / \mathrm{Hf}$ also infer a moderate to high degree of fractionation in the pegmatite melts. Similarly, the immobile elemental magmatic affinity plot of [80] in $\mathrm{Yb}$ vs Th (ppm) diagram data indicate calc-alkaline affinity (Figure 5(I)) and in $\mathrm{Yb}$ vs La (ppm) samples plot in the tholeiitic to transitional field and samples of lepidolite pegmatite in
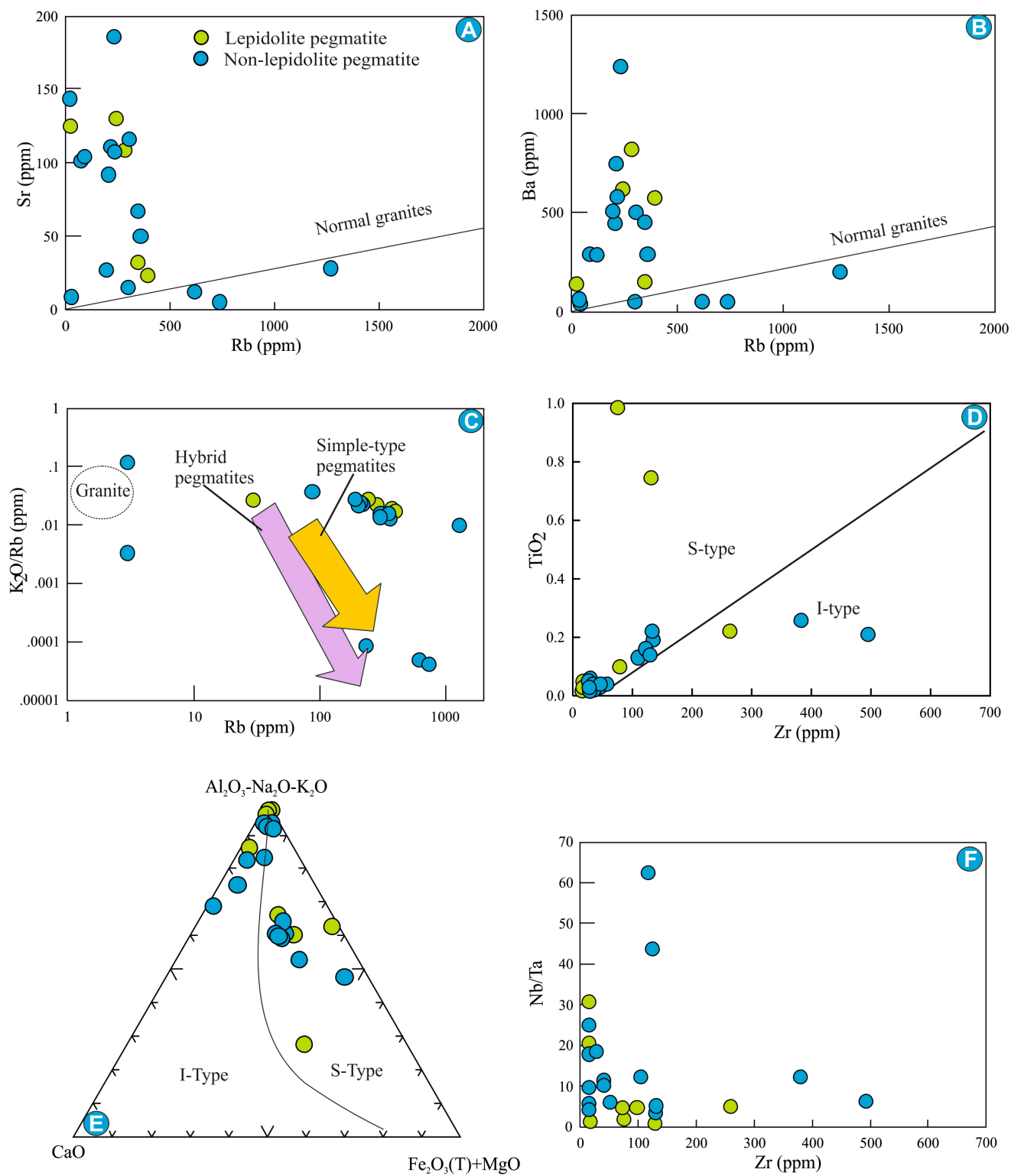

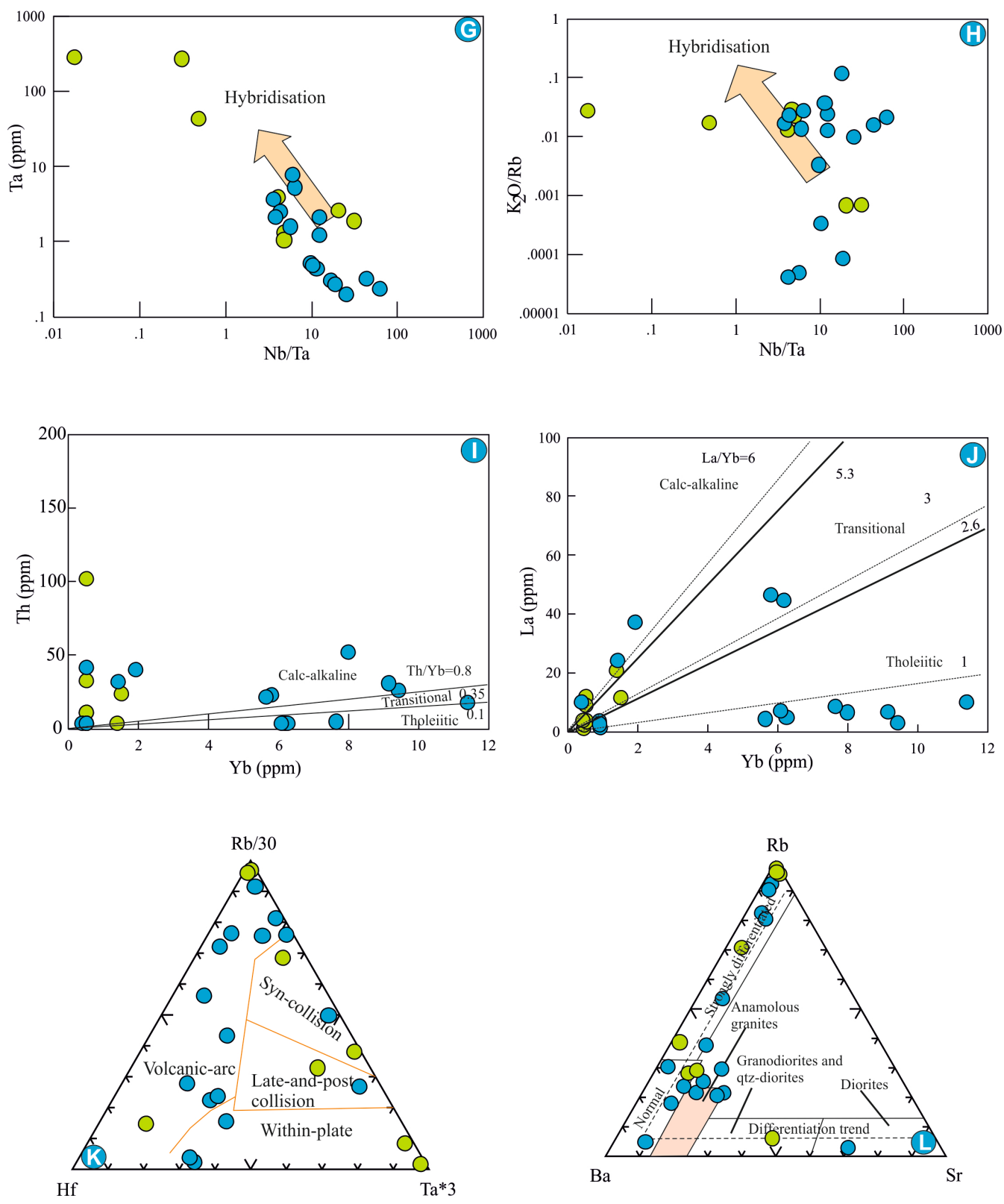

Figure 5. (A) $\mathrm{Rb}$ vs $\mathrm{Sr} \&(\mathrm{~B}) \mathrm{Rb}$ vs $\mathrm{Ba}(\mathrm{ppm})$ diagrams the studied samples plotted above the normal granite field showing variable degrees of fractionation of pegmatites, (C) $\mathrm{Rb}$ vs $\mathrm{K}_{2} \mathrm{O} / \mathrm{Rb}$ (ppm) diagram, the analysed data plot near the arrow of simple type pegmatite and few samples scattered around hybrid pegmatite (after, [78]), (D) The trace element $\mathrm{Zr}$ vs $\mathrm{TiO}_{2}$ diagram indicate mainly S-type granitic source for both the pegmatites (after, [79]), (E) In triangular $\mathrm{CaO}-\mathrm{Al}_{2} \mathrm{O}_{3}-\mathrm{Na}_{2} \mathrm{O}-\mathrm{K}_{2} \mathrm{O}-\mathrm{Fe}_{2} \mathrm{O}_{3 \mathrm{~T}}+\mathrm{MgO}$ diagram indicate mainly S-type field and I-type field for some samples (after, [77]), (F) $\mathrm{Zr}$ vs Nb/Ta (ppm) diagram indicate enrichment and fractionation of $\mathrm{Nb}$ (after, [78]), (G) In $\mathrm{Nb} / \mathrm{Ta}$ vs Ta samples plot in lower end of hybridization arrow and few towards the arrow head, $(\mathrm{H}) \mathrm{Nb} / \mathrm{Ta}$ vs $\mathrm{K}_{2} \mathrm{O} / \mathrm{Rb}$ diagram samples plot around hybridization arrow indicate more fractionation of $\mathrm{Ta}$ and $\mathrm{Rb}$ in lepidolite pegmatite, (I) $\mathrm{Yb}$ vs Th (ppm) diagram data indicate calc-alkaline affinity in immobile elemental magmatic affinity plot [80], (J) Yb vs La (ppm) samples plot in the tholeiitic to transitional field and samples of lepidolite pegmatite in transitional to calc-alkaline field, $(\mathrm{K})$ Ternary $\mathrm{Hf}-\mathrm{Rb} / 30-\mathrm{Ta}^{*} 3$ diagram reflects mainly within plate tectonic field, and for some samples all other fields [81] and (L) Ba-Rb-Sr ternary diagram represent normal to strongly differentiated trend of granite/pegmatite (after, [76]). Symbols are same as used in Figure 4. 
transitional to calc-alkaline field (Figure $5(\mathrm{~J})$ ). Ternary $\mathrm{Hf}-\mathrm{Rb} / 30-\mathrm{Ta}^{\star} 3$ diagram [81] samples reflect within plate and volcanic arc tectonic fields, and for some samples all other fields (Figure $5(\mathrm{~K})$ ) and Ba-Rb-Sr ternary diagram (after, [75]) represent normal to strongly differentiated trend of granite/pegmatite with few samples as anomalous granite (Figure 5(L)).

\section{3) Rare Earth Element geochemistry}

The Rare Earth Element (REE) data of both the pegmatites is presented in Table 4 . The REE spider and multi-element spider variation diagrams were plotted using these data.

Rare Earth Element is relatively low to moderate. LREE i.e. La ranging from 1 to $20.76 \mathrm{ppm}$, Ce from 2 to $59.51 \mathrm{ppm}$ and Nd from 0.88 to $27.53 \mathrm{ppm}$. HREE i.e. $\mathrm{Gd}$ from 0.50 to $4.73 \mathrm{ppm}, \mathrm{Tb}$ from 0.50 to $0.83 \mathrm{ppm}$, Dy from 0.50 to 4.40 ppm, Ho from 0.50 to $0.65 \mathrm{ppm}$, and Er from 0.50 to $1.59 \mathrm{ppm}$. The REE spider

Table 4. Rare Earth Element data of lepidolite pegmatites (samples of L-series) and non-lepidolite pegmatite (samples of P-series).

\begin{tabular}{|c|c|c|c|c|c|c|c|c|c|c|c|c|c|c|c|c|c|}
\hline Sample & $\mathrm{La}$ & $\mathrm{Ce}$ & $\operatorname{Pr}$ & Nd & $\mathrm{Sm}$ & $\mathrm{Eu}$ & Gd & $\mathrm{Tb}$ & Dy & Ho & Er & $\operatorname{Tm}$ & $\mathrm{Yb}$ & $\mathrm{Lu}$ & TREE & LREE & HREE \\
\hline L-1 & 1.23 & 2.00 & 0.50 & 0.68 & 0.50 & 0.50 & 0.50 & 0.50 & 0.50 & 0.50 & 0.50 & 0.50 & 0.50 & 0.50 & 9.41 & 5.41 & 4.00 \\
\hline L-89 & 11.83 & 7.20 & 2.77 & 27.53 & 2.12 & 0.50 & 2.11 & 0.50 & 2.37 & 0.50 & 0.54 & 0.50 & 0.50 & 0.50 & 59.47 & 51.95 & 7.52 \\
\hline L-90 & 1.00 & 2.00 & 0.50 & 1.03 & 0.50 & 0.50 & 0.50 & 0.50 & 1.21 & 0.50 & 0.50 & 0.50 & 0.50 & 0.50 & 10.23 & 5.53 & 4.71 \\
\hline L-95 & 1.00 & 2.00 & 0.50 & 2.61 & 0.50 & 0.50 & 0.50 & 0.50 & 0.50 & 0.50 & 0.50 & 0.50 & 0.50 & 0.50 & 11.11 & 7.11 & 4.00 \\
\hline L-99 & 20.76 & 13.79 & 4.87 & 26.05 & 4.42 & 1.07 & 4.70 & 0.83 & 4.40 & 0.65 & 1.59 & 0.50 & 1.38 & 0.50 & 85.50 & 70.95 & 14.55 \\
\hline L-100 & 9.14 & 6.31 & 2.16 & 15.59 & 1.55 & 0.50 & 1.21 & 0.50 & 1.29 & 0.50 & 0.50 & 0.50 & 0.50 & 0.50 & 40.76 & 35.26 & 5.50 \\
\hline L-112 & 11.65 & 59.51 & 2.72 & 25.22 & 2.21 & 0.58 & 2.83 & 0.50 & 3.11 & 0.50 & 1.45 & 0.50 & 1.52 & 0.50 & 112.82 & 101.90 & 10.92 \\
\hline Lep-1 & 1.69 & 2.00 & 0.50 & 0.88 & 0.50 & 0.50 & 0.50 & 0.50 & 0.50 & 0.50 & 0.50 & 0.50 & 0.50 & 0.50 & 10.07 & 6.07 & 4.00 \\
\hline P-8 & 46.36 & 87.01 & 11.52 & 48.73 & 9.84 & 2.29 & 10.36 & 1.53 & 9.07 & 1.88 & 5.60 & 1.04 & 5.78 & 0.97 & 241.99 & 205.76 & 36.22 \\
\hline P-20 & 1.49 & 2.53 & 0.32 & 1.60 & 0.61 & 0.07 & 0.14 & 0.68 & 0.75 & 0.12 & 0.38 & 0.07 & 0.50 & 0.08 & 9.33 & 6.61 & 2.72 \\
\hline P-32 & 37.23 & 89.31 & 9.54 & 34.10 & 7.61 & 1.03 & 6.04 & 0.74 & 3.51 & 0.61 & 1.71 & 0.50 & 1.92 & 0.50 & 194.33 & 178.81 & 15.52 \\
\hline$P-51$ & 3.09 & 4.11 & 0.73 & 71.50 & 1.33 & 0.76 & 5.11 & 1.89 & 14.22 & 2.77 & 9.32 & 1.82 & 9.42 & 1.45 & 127.54 & 81.52 & 46.02 \\
\hline P-39 & 6.57 & 17.28 & 1.45 & 8.64 & 2.24 & 0.90 & 4.82 & 1.35 & 10.72 & 2.38 & 7.71 & 1.33 & 7.98 & 1.18 & 74.55 & 37.07 & 37.48 \\
\hline P-110 & 4.83 & 7.33 & 0.88 & 17.45 & 1.31 & 0.69 & 3.12 & 0.91 & 7.31 & 1.62 & 5.56 & 1.13 & 6.24 & 0.94 & 59.33 & 32.50 & 26.83 \\
\hline P-113 & 8.77 & 14.44 & 1.76 & 18.78 & 2.01 & 0.70 & 4.04 & 1.08 & 8.69 & 2.00 & 6.91 & 1.40 & 7.64 & 1.17 & 79.39 & 46.46 & 32.93 \\
\hline P-209 & 6.87 & 19.29 & 1.81 & 8.32 & 2.36 & 0.86 & 2.90 & 0.97 & 8.73 & 2.36 & 7.55 & 1.38 & 9.12 & 1.50 & 74.03 & 39.52 & 34.51 \\
\hline P-230 & 10.18 & 27.87 & 2.56 & 15.81 & 3.47 & 0.50 & 4.15 & 1.24 & 10.33 & 2.66 & 8.71 & 1.63 & 11.39 & 1.90 & 102.38 & 60.39 & 41.99 \\
\hline P-5 & 2.78 & 3.24 & 0.52 & 1.84 & 0.51 & 0.50 & 0.50 & 0.50 & 0.50 & 0.50 & 0.50 & 0.50 & 0.50 & 0.50 & 13.40 & 9.39 & 4.00 \\
\hline P-9 & 10.21 & 25.31 & 0.35 & 0.22 & 0.25 & 0.01 & 0.09 & 0.37 & 0.51 & 0.08 & 0.27 & 0.04 & 0.38 & 0.06 & 38.14 & 36.36 & 1.79 \\
\hline P-11 & 4.34 & 10.17 & 0.94 & 6.24 & 1.45 & 0.84 & 3.38 & 0.92 & 7.43 & 1.69 & 5.38 & 0.91 & 5.63 & 0.83 & 50.15 & 23.98 & 26.17 \\
\hline P-12 & 6.98 & 11.03 & 1.29 & 20.99 & 1.51 & 0.70 & 3.17 & 0.93 & 7.29 & 1.60 & 5.61 & 1.07 & 6.08 & 0.93 & 69.18 & 42.51 & 26.67 \\
\hline P-25 & 1.38 & 2.00 & 0.50 & 2.51 & 0.50 & 0.50 & 0.50 & 0.50 & 0.75 & 0.50 & 0.50 & 0.50 & 0.50 & 0.50 & 11.63 & 7.39 & 4.25 \\
\hline
\end{tabular}


diagram (Figure 6(A) \& Figure 6(B)) and multi element spider diagram (Figure 6(C) \& Figure 6(D)) after [82] represented following observations. The chondrite-normalized spider diagram indicates slightly enriched LREE pattern (La, Ce, Pr, Nd, Pm, Sm, Eu), than HREE (Gd, Tb, Dy, Er, Tm, Yb, Lu) in lepidolite pegmatite. However, there is enrichment of MREE (Eu, Gd, Tb, Dy, Er) and HREE in non-lepidolite pegmatite. LREE enrichment correlates with monazite and allanite, which host the LREE in these rocks [83]. There is negative and positive Europium anomaly for some samples in both the pegmatites, which indicate fluctuation in the crystallization of plagioclase in the source region or presence of plagioclase in minor amount in the magma. Pronounced negative anomalies such as Ce, Nd, Gd, Dy, Er and Yb indicate absence of posphatic minerals in the magma. Whereas, strong positive anomalies such as $\mathrm{Pr}, \mathrm{Pm}, \mathrm{Tb}, \mathrm{Ho}$ and Tm indicate garnet and amphibole in the source region. On chondrite-normalized multi-element diagrams [82], high field strength elements (HFSE), such as $\mathrm{Zr}$ and $\mathrm{Nb}$ show negative anomalies. These anomalies may result from the preservation of such elements in residual phases when magmas have been generated in a subduction zone by partial melting of source rocks (see [84]). Positive anomaly of $\mathrm{Rb}$ in multi-elements spider diagram may have resulted from late stage crystallization of muscovite and $\mathrm{K}$-feldspar from magma. Barium, and $\mathrm{Sr}$ negative anomalies can be due to their co-substitution in plagioclase, which crystallizes at early stages.

On the whole, enrichment in some LILE, such as $\mathrm{K}, \mathrm{Rb}$, and Th and depletion
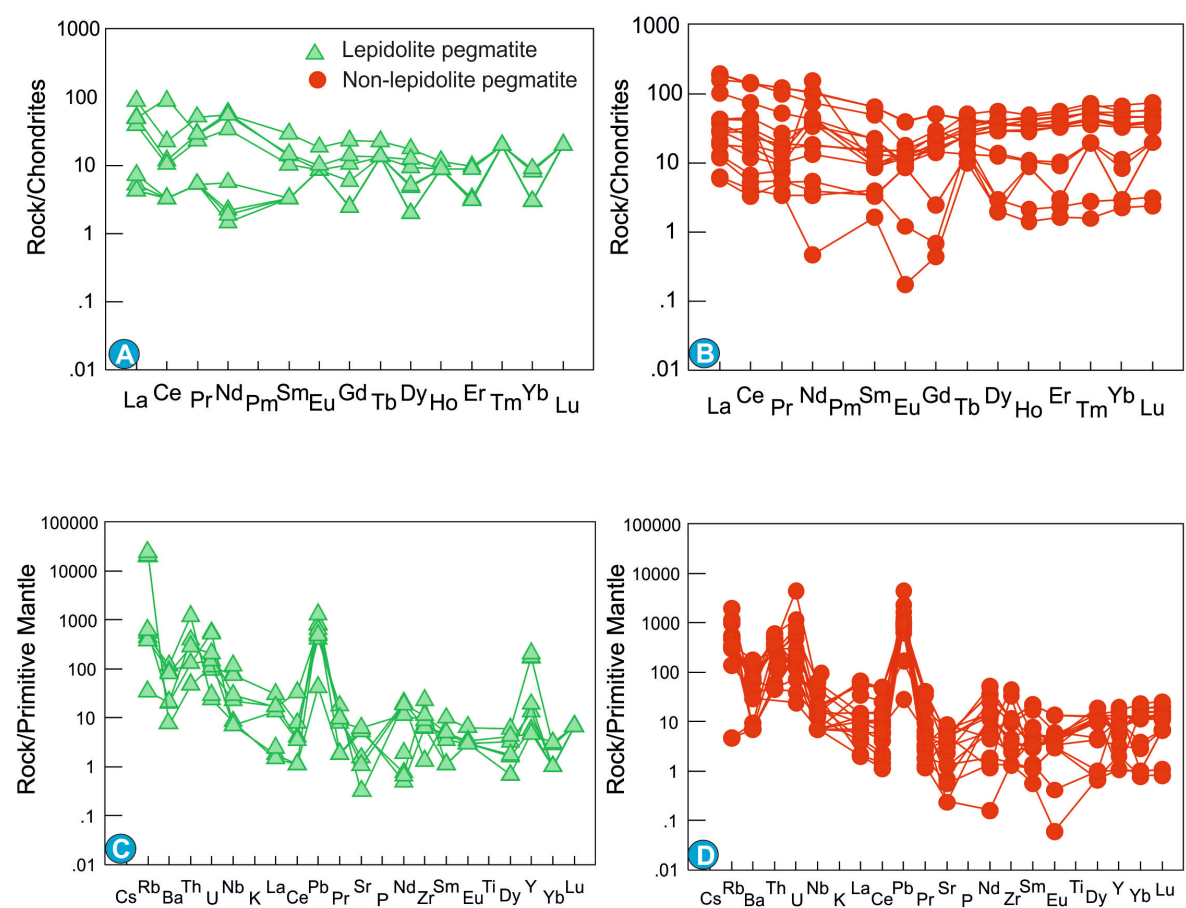

Figure 6. (A) \& (B) The REE spider diagram for lepidolite pegmatite and non-lepidolite pegmatite (after, [82]), (C) \& (D) Multi element primitive mantle spider diagram for lepidolite pegmatite and non-lepidolite pegmatite (after, [82]). 
in some HFSE, such as $\mathrm{Nb}, \mathrm{Ti}, \mathrm{Zr}$, and $\mathrm{Y}$, and HREE can be related to melting and fractionation processes in the region [85] [86]. According to the LCT (Li$\mathrm{Cs}$-Ta) family of pegmatites contains high concentrations of $\mathrm{Rb}, \mathrm{Cs}, \mathrm{Be}, \mathrm{Ta}, \mathrm{Nb}$, and $\mathrm{Sn}$, as well as elevated levels of fluxing components (Li, P, F, and B). Accordingly, the studied lepidolite pegmatites have high concentration of $\mathrm{Rb}$ (up to $393 \mathrm{ppm}$; three samples have 12,409, 13,138 \& 15,537 ppm), Ta (up to 269.86 ppm), Nb (up to $83 \mathrm{ppm}$ ), and Sn (312.85 ppm). High amounts [87] of HFSE elements, such as Th (up to $102 \mathrm{ppm}$ ), U (up to $11.26 \mathrm{ppm}$ ), and $\mathrm{Zr}$ (up to 259 ppm) are may be due to occurrence of some minerals, such as Th-silicate, U-silicate, U-oxides, and zircon in pegmatites. Accordingly, the studied non lepidolite pegmatites have high concentration of $\mathrm{Rb}$ (up to $1268 \mathrm{ppm}$ ), $\mathrm{Nb}$ (up to 46 $\mathrm{ppm}$ ), HFSE element such as Th (up to $42 \mathrm{ppm}$ ), $\mathrm{U}$ (up to $93.36 \mathrm{ppm}$ ), and $\mathrm{Zr}$ (up to $493 \mathrm{ppm}$ ) are might be due to occurrence of some minerals, such as Th-silicate, U-silicate, U-oxides, and zircon in pegmatites. These above REE studies emphasize the highly fractionated nature of both these pegmatites from the granitic source.

\section{Conclusion}

On the basis of field characters, pegmatites are intrusive as small to large veins in the biotite gneiss and amphibolite with lepidolite as important mineral. Geochemically, they are calc-alkaline to high calc-alkaline and per-aluminous in characters. On the basis of Alumina Saturation Index (ASI), these pegmatites are resembling to Lithium-Cesium-Tantalum (LCT) family of pegmatites. Most pegmatites with the LCT signature have compositional affinity with S-type granites of orogenic environments (i.e., subduction zones or continental collision zones). Trace element compositions ( $\mathrm{Rb}, \mathrm{Sr}, \mathrm{Ba}$ ) indicate crystal fractionations, variable degrees of fractionation and highly evolved nature of pegmatites from the granitic source. The different tectonic discrimination diagrams indicate Stype and I-type melt for pegmatite derivations. High amounts of Rb in the studied pegmatites, indicate that these samples are placed in the category of strongly differentiated granites in the ternary $\mathrm{Rb}-\mathrm{Ba}-\mathrm{Sr}$ plot. Therefore, both the studied pegmatites could be an evolved variety of granitic rocks that originated from the same magma. The REE is relatively low to moderate and slightly enriched LREE pattern in lepidolite pegmatite. However, there is enrichment of MREE and HREE in non-lepidolite pegmatite.

\section{Acknowledgements}

The authors are grateful to the DDG \& RMH-II, GSI, NER Shillong is for his kind guidance and encouragement during the field work. RRM collected the samples during his field visits with the help of project officers and he indebted to them for their help in the field. Due acknowledgment is given to the Geological Survey of India for providing all facilities. The Petrology Division and Mineral Physics Division, GSI, CR is acknowledged for their kind help for lab studies. 
The authors also acknowledge anonymous reviewers for their constructive and thoughtful comments, which helps for improving the manuscript's quality.

\section{Conflicts of Interest}

The authors declare no conflicts of interest regarding the publication of this paper.

\section{References}

[1] London, D. (2008) Pegmatites. The Canadian Mineralogist, 10, 347.

[2] Cerný, P. (1991) Rare-Element Granite Pegmatites. Part I: Anatomy and Internal Evolution of Pegmatite Deposits. Part II: Regional to Global Relationships and Petrogenesis. Geoscience Canada, 18, 49-81.

[3] Taylor, R.P. and Strong, D.F. (1985) Recent Advances in the Geology of Granite-Related Mineral Deposits: Proceedings of the CIM Conference on Granite-Related Mineral Deposits. Canadian Institute of Mining and Metallurgy, Vol. 39, 1-445.

[4] Norton, J.J. and Redden, J.A. (1990) Relations of Zoned Pegmatites to Other Pegmatites, Granite, and Metamorphic Rocks in the Southern Black Hills, South Dakota. American Mineralogist, 75, 631-655.

[5] Babu, T.M. (1994) Tin in India. Mineral Resources in India, Geological Society of India, Vol. 7, 217 p.

[6] Simmons, S. (2007) Recent Advances and Areas for Future Research. Granitic Pegmatites. The State of the Art-International Symposium, Porto, 6-12 May 2007, 1-4.

[7] Wise, M.A. and Brown, C.D. (2010) Mineral Chemistry, Petrology and Geochemistry of the Sebago Granite Pegmatite System, Southern Maine, USA. Journal of Geosciences, 55, 3-26. https://doi.org/10.3190/igeosci.061

[8] Linnen, R.L., Lichtervelde, M.V. and Cerny, P. (2012) Granitic Pegmatites as Sources of Strategic Metals. Elements, 8, 275-280. https://doi.org/10.2113/gselements.8.4.275

[9] Dill, H.G. (2015) Pegmatites and Aplites: Their Genetic and Applied Ore Geology. Ore Geology Reviews, 69, 417-456. https://doi.org/10.1016/j.oregeorev.2015.02.022

[10] London, D. and Morgan, G.V.I. (2012) The Pegmatite Puzzle. Elements, 8, 263-268. https://doi.org/10.2113/gselements.8.4.263

[11] Cerný, P. and Ercit, T.S. (2005) The Classification of Granitic Pegmatites Revisited. The Canadian Mineralogist, 43, 2005-2026. https://doi.org/10.2113/gscanmin.43.6.2005

[12] Cameron, E.N., Jahns, R.H., McNair, A.H. and Page, L.R. (1949) Internal Structure of Granitic Pegmatites. Society of Economic Geologists, Vol. 2, 115 p.

[13] Jahns, R.H. and Burnham, C.W. (1969) Experimental Studies of Pegmatite Genesis. I. A Model for the Derivation and Crystallization of Granitic Pegmatites. Economic Geology, 64, 843-864. https://doi.org/10.2113/gsecongeo.64.8.843

[14] Trueman, D.L. and Černý, P. (1982) Exploration for Rare-Element Granitic Pegmatites. In: Černý, P., Ed., Granitic Pegmatites in Science and Industry, Association of Canada Short Course Handbook, Mineral, Vol. 8, 463-494.

[15] Babu, V.R.R.M. (1969) Temperatures of Formation of Pegmatites of Nellore Mica Belt, Andhra Pradesh, India. Economic Geology, 64, 66-71.

https://doi.org/10.2113/gsecongeo.64.1.66 
[16] Bhola, K.L. (1971) Atomic Mineral Deposits in Bihar Mica-Belt. Proceedings of the Indian National Science Academy, 37, 145-168.

[17] Datta, A.K. (1973) Internal Structure, Petrology and Mineralogy of Calc-Alkaline Pegmatites in Parts of Rajasthan. Memoirs of the Geological Survey of India, Vol. 110, 1-112.

[18] Ramaswamy, C., Deshpande, M.L., Murthy, K.S., Jaiswar, H.P. and Jesani, R.S. (1976) Tin-Bearing Pegmatites of Bastar, M.P. Geological Survey of India Special Publication Vol. 3, 185-189.

[19] Lamba, V.J.S. and Khanna, V.K. (1981) Characteristic Feature of Tin-Bearing Rare Metal Pegmatites of Konta Tahsil, Bastar District, M.P. Bulletin of the Indian Geologists Association, 14, 151-154.

[20] Babu, P.V.R., Pandey, B.K. and Dhana Raju, R. (1993) Rb-Sr Ages on the Granite and Pegmatitic Minerals from Bastar-Koraput Pegmatite Belt, Madhya Pradesh and Orissa, India. Journal of the Geological Society of India, 42, 33-38.

[21] Som, S.K., Bandyopadhyay, K.C., Basu, S.K., Santra, D.K. and Ghosh, R.N. (2002) Li-Cs-Rb Mineralization in Proterozoic Zoned Pegmatites of Beku, West Bengal. Journal of the Geological Society of India, 60, 493-503.

[22] Deshpande, M.L. (1976) The Cassiterite-Lepidolite-Bearing Pegmatites in the Bastar District, Madhya Pradesh. Indian Minerals, 30, 67-74.

[23] Singh, Y. (1998) Early Proterozoic Rare Metal and Tin Pegmatites near Kawadgaon, Bastar, M.P: An Example of Vertical Pegmatite Zonation. Journal of the Geological Society of India, 51, 175-182.

[24] Singh, Y., Pandit, P.S.C., Bagora, S. and Jain, P.K. (2017) Mineralogy, Geochemistry, and Genesis of Co-Genetic Granite-Pegmatite-Hosted Rare Metal and Rare Earth Deposits of the Kawadgaon Area, Bastar Craton, Central India. Journal of the Geological Society of India, 89, 113-228. https://doi.org/10.1007/s12594-017-0574-2

[25] Rieder, M., Cavazzini, G., D’yakonov, Yu.S., FrankKamenetskii, V.A., Gottardi, G., Guggenheim, S., Koval', P.V., Muller, G., Neiva, A.M.R., Radoslovich, E.W., Robert, J.-L., Sassi, F.P., Takeda, H., Weiss, Z. and Wones, D.R. (1998) Nomenclature of the Micas. The Canadian Mineralogist, 36, 905-912. https://doi.org/10.1346/CCMN.1998.0460513

[26] Tischendorf, G., Forster, H.J. and Gottesmann, B. (2001) Minor and Trace-Element Composition of Tri-Octahedral Micas: A Review. Mineralogical Magazine, 65, 249276. https://doi.org/10.1180/002646101550244

[27] Černý, P. and Burt, D.M. (1984) Paragenesis, Crystallo-Chemical Characteristics and Geochemical Evolution of Micas in Granite Pegmatites. In: Bailey, S.W., Ed., Micas, Reviews in Mineralogy, Vol. 13, De Gruyter, Berlin, 257-297. https://doi.org/10.1515/9781501508820-012

[28] Guidotti, C.V. (1984) Micas in Igneous Rocks. In: Bailey, S.W., Ed., Micas, Reviews in Mineralogy Vol. 13, Mineralogical Society of America, Washington DC, 357-467. https://doi.org/10.1515/9781501508820-014

[29] Hewitt, D.A. and Wones, D.R. (1984) Experimental Phase Relations of Micas. In: Bailey, S.W., Ed., Micas, Reviews in Mineralogy Vol. 13, Mineralogical Society of America, Washington DC, 201-256. https://doi.org/10.1515/9781501508820-011

[30] Speer, J.A. (1984) Micas in Igneous Rocks. In: Bailey, S.W., Ed., Micas, Reviews in Mineralogy Vol. 13, Mineralogical Society of America, Washington DC, 299-356. https://doi.org/10.1515/9781501508820-013

[31] Henderson, C.M.B., Martin, J.S. and Mason, R.A. (1989) Compositional Relations in 
Li-Micas from S.W. England and France: An Ion- and Electron-Microprobe Study. Mineralogical Magazine, 53, 427-449. https://doi.org/10.1180/minmag.1989.053.372.03

[32] du Bray, E.A. (1994) Compositions of Micas in Peraluminous Granitoids of the Eastern Arabian Shield. Implications for Petrogenesis and Tectonic Setting of Highly Evolved, Rare Metal Enriched Granites. Contributions to Mineralogy and Petrology, 116, 381-397. https://doi.org/10.1007/BF00310906

[33] Mohamed, F.H., Abdalla, H.M. and Helba, H. (1999) Chemistry of Micas in RareMetal Granitoids and Associated Rocks, Eastern Desert, Egypt. International Geology Review, 41, 932-948. https://doi.org/10.1080/00206819909465180

[34] Lowell, G.R. and Ahl, M. (2000) Chemistry of Dark Zinnwaldite from Bom Futuro Tin Mine, Rondonia, Brazil. Mineralogical Magazine, 64, 699-709. https://doi.org/10.1180/002646100549553

[35] Rao, M.G. (1964) Systematic Geological Mapping in the Southern Part of Goalpara District, Assam. Geological Survey of India Unpublished Progress Report for FS 1962-63.

[36] Gogoi, K. (1970) Report on Detailed Investigation for Lepidolite Mica on the Northern Tip of the Dhir Bil, Goalpara District, Assam. Geological Survey of India FS 1969-70.

[37] Barman, J., David, J.S. and Sarma, G. (1989) Preliminary Appraisal of Reported Lepidolite Occurrence around Dhir Bil, Dhubri District, Assam. Record Geological Survey of India, 122, 28.

[38] Agrawal, N.K. and David, J.S. (1990) Preliminary Appraisal of Reported Lepidolite Occurrence around Dhir Bil, Dhubri District, Assam. Record Geological Survey of India, 123, 43.

[39] Agrawal, N.K. and David, J.S. (1993) Preliminary Appraisal of Reported Lepidolite Occurrence around Dhir Bil, Dhubri District, Assam. Geological Survey of India FS 1988-89.

[40] Mishra, M.K. and Singh, B. (2017) Investigation for W, Sn \& REE in the Chakrasila, Nadangiri and Bhumeswar in the Bongaigaon, Dhubri and Kokrajhar Districts, Assam. Geological Survey of India FS 2014-16.

[41] Crawford, A.R. (1974) Indo-Antarctica, Gondwana Land and Pattern of the Distortion of a Granulite Belt. Tectonophysics, 22, 141-157. https://doi.org/10.1016/0040-1951(74)90038-9

[42] Desikachar, S.V. (1974) A Review of the Tectonic and Geological History of Eastern India in Terms of Plate Tectonic Theory. Geological Survey of India, Vol. 15, $137-$ 149.

[43] Khonglah, M.A., Khan, M.A., Karim, M.A., Kumar, A. and Choudhury, J. (2008) Geology and Structure of the Areas in and around Shillong, Meghalaya, North East India, Revisited. Proceedings of the National Seminar on Geology \& Energy Resources of NE India: Progress \& Perspectives Nagaland University Research Journal Special Pub.

[44] Srivastava, R.K. and Sinha, A.K. (2004) The Early Cretaceous Sung Valley Ultramafic-Mafic-Alkaline-Carbonatite Complex, Shillong Palateau, Northeastern India: Petrological and Genetic Significance. Mineralogy and Petrology, 80, 241-263. https://doi.org/10.1007/s00710-003-0025-1

[45] Bidyanand, M. and Deomurari, M.P. (2007) Geochronological Constraints on the Evolution of Meghalaya Massif, Northeastern India: An Ion Microprobe Study. Current Science, 93, 1620-1623. 
[46] Kumar, S., et al. (2017) Contribution of Columbia and Gondwana Supercontinent Assembly- and Growth-Related Magmatism in the Evolution of the Meghalaya Plateau and the Mikir Hills, Northeast India: Constraints from U-Pb SHRIMP Zircon Geochronology and Geochemistry. Lithos, 277, 356-375.

https://doi.org/10.1016/j.lithos.2016.10.020

[47] Chatterjee, N., Bhattacharya, A., Duarah, B.P. and Mazumdar, A.C. (2011) Late Cambrian Reworking of Paleo-Mesoproterozoic Granulites in Shillong-Meghalaya Gneissic Complex (Northeast India): Evidence from PT Pseudosection Analysis and Monazite Chronology and Implications for East Gondwana Assembly. The Journal of Geology, 119, 311-330. https://doi.org/10.1086/659259

[48] Chatterjee, N., Mazumdar, A.C., Bhattacharya, A. and Saikia, R.R. (2007) Mesoproterozoic Granulites of the Shillong-Meghalaya Plateau: Evidence of Westward Continuation of the Prydz Bay Pan-African Suture into Northeastern India. Precambrian Research, 152, 1-26. https://doi.org/10.1016/j.precamres.2006.08.011

[49] Ghosh, S., Fallick, A.E., Paul, D.K. and Potts, P.J. (2005) Geochemistry and Origin of Neoproterozoic Granitoids of Meghalaya, Northeast India: Implications for Linkage with Amalgamation of Gondwana Supercontinent. Gondwana Research, 8, 421-432. https://doi.org/10.1016/S1342-937X(05)71144-8

[50] Mitra, S.K. (1998) Structure, Sulphide Mineralization and Age of the Shillong Group of Rocks, Meghalaya. Commemorative National Seminar, Kolkata, 1 and 2 November 1998, 118-119.

[51] Yin, A., Dubey, C.S., Webb, A.A.G., Kelty, T.K., Grove, M., Gehrels, G.E. and Burgess, W.P. (2010) Geologic Correlation of the Himalayan Orogen and Indian Craton: Part 1. Structural Geology, U-Pb Zircon Geochronology, and Tectonic Evolution of the Shillong Plateau and Its Neighboring Regions in NE India. Geological Society of America Bulletin, 122, 336-359. https://doi.org/10.1130/B26460.1

[52] Nandi, D.R. (2001) Geodynamics of the Northeastern India and the Adjoining Region. ACB. Publ. 209 p.

[53] Crawford, A.R. (1969) India, Ceylon and Pakistan: New Age Data and Comparison with Australia. Nature, 223, 80-84. https://doi.org/10.1038/223380a0

[54] Mazumder, S.K. (1976) A Summary of the Precambrian Geology of Khasi Hills, Meghalaya. Miscellaneous Publications of the Geological Survey of India Vol. 23, pt. 2, 311-334.

[55] Chimote, J.S., Pandey, B.K., Bagchi, A.K., Basu, A.N., Gupta, J.N. and Sarsawat, A.C. (1988) Rb-Sr Whole-Rock Isochron Age for the Myllium Granite, Khasi Hills, Meghalaya. Fourth National Symposium on Mass Spectrometry, Bangalore, EPs9/1-9/4.

[56] Van Breeman, O., Bowes, D.R., Bhattacharjee, C.C. and Chowdhary, P.K. (1989) Late Proterozoic-Early Proterozoic Rb-Sr Whole Rock and Mineral Ages for Granite and Pegmatite, Goalpara, Assam, India. Journal of the Geological Society of India, 34, 89-92.

[57] Ghosh, S., Bhalla, J.K., Paul, D.K., Sarkar, A., Bishui, P.K. and Gupta, S.N. (1991) Geochronology and Geochemistry of Granite Plutons from East Khasi Hills, Meghalaya. Journal of the Geological Society of India, 37, 331-342.

[58] Ghosh, S., Chakraborty, S., Paul, D.K., Bhalla, J.K., Bishui, P.K. and Gupta, S.N. (1994) New Rb-Sr Isotopic Ages and Geochemistry of Granitoids from Meghalaya and Their Significance in Middle to Late Proterozoic Crustal Evolution. Indian Minerals, 48, 33-44.

[59] Bilham, R. and England, P. (2001) Plateau "Pop-Up" in the Great 1897 Assam 
Earthquake. Nature, 410, 806-809. https://doi.org/10.1038/35071057

[60] Oldham, R.D. (1899) Report on the Great Earthquake of 12th June, 1897. Memoirs of the Geological Survey of India, Vol. 29, 379.

[61] GSI (2009) Geology and Mineral Resources of Assam. Misc. Publ. No. 30 pt-IV. V. 2 (i), 7-9.

[62] Cox, K.G., Bell, J.D. and Pankhurst, R.J. (1979) The Interpretation of Igneous Rocks. George Allen and Unwin, London.

https://doi.org/10.1007/978-94-017-3373-1

[63] Peccerillo, A. and Taylor, S.R. (1976) Geochemistry of Eocene Calc-Alkaline Rocks from Kastamonu Area, Northern Turkey. Contributions to Mineralogy and Petrology, 58, 63-81. https://doi.org/10.1007/BF00384745

[64] Shand, S.J. (1943) Eruptive Rocks. Their Genesis, Composition, Classification, and Their Relation to Ore-Deposits with a Chapter on Meteorite. John Wiley \& Sons, New York.

[65] Maniar, P.D. and Piccoli, P.M. (1989) Tectonic Discrimination of Granitoids. Geological Society of America Bulletin, 10, 635-643. https://doi.org/10.1130/0016-7606(1989)101<0635:TDOG >2.3.CO;2

[66] Frost, R.B., Barnes, C.G., Collins, W.J., Arculus, R.J., Ellis, D.J. and Frost, C.D. (2001) A Geochemical Classification for Granitic Rocks. Journal of Petrology, 42, 2033-2048. https://doi.org/10.1093/petrology/42.11.2033

[67] Landenberger, B. and Collins, W.J. (1996) Derivation of A-Type Granites from a Dehydrated Charnockitic Lower Crust: Evidence from the Chaelundi Complex, Eastern Australia. Journal of Petrology, 37, 145-170.

https://doi.org/10.1093/petrology/37.1.145

[68] Dall'Agnol, R. and de Oliveira, D.C. (2007) Oxidized, Magnetite Series, Rapakivi-Type Granites of Carajas, Brazil: Implications for Classification and Petrogenesis of A-Type Granites. Lithos, 93, 215-233. https://doi.org/10.1016/j.lithos.2006.03.065

[69] Chappell, B.W. and White, A.J.R. (2001) Two Contrasting Granite Types: 25 Years Later. Australian Journal of Earth Sciences, 48, 489-499.

https://doi.org/10.1046/j.1440-0952.2001.00882.x

[70] Cerný, P. (1992) Geochemical and Petrogenetic Features of Mineralization in Rare Element Granitic Pegmatites in the Light of Current Research. Applied Geochemistry, 7, 393-416. https://doi.org/10.1016/0883-2927(92)90002-K

[71] Martin, R.F. and Vito, C.D. (2005) The Patterns of Enrichment in Felsic Pegmatites Ultimately Depend on Tectonic Setting. The Canadian Mineralogist, 43, 2027-2048. https://doi.org/10.2113/gscanmin.43.6.2027

[72] Cerný, P., London, D. and Novak, M. (2012) Granitic Pegmatites as Reflections of Their Source. Elements, 8, 289-294. https://doi.org/10.2113/gselements.8.4.289

[73] Cerný, P., Meintzer, R.E. and Anderson, A.J. (1985) Extreme Fractionation in RareElement Granitic Pegmatites: Selected Examples of Data and Mechanisms. The Canadian Mineralogist, 23, 381-421.

[74] Alfonso, P., Melgarejo, J.C., Yusta, I. and Velasco, F. (2003) Geochemistry of Feldspars and Muscovite in Granitic Pegmatite from the Capde Creusfield, Catalonia, Spain. The Canadian Mineralogist, 41, 103-116. https://doi.org/10.2113/gscanmin.41.1.103

[75] Lentz, D. (1996) U, Mo, and REE Mineralization in Latetectonic Granitic Pegmatites, Southwestern Grenville Province. Ore Geology Reviews, 11, 197-227.

https://doi.org/10.1016/0169-1368(95)00034-8 
[76] El Bouseily, A.M. and El Sokkary, A.A. (1975) The Relation between Rb, Ba and Sr in Granitic Rocks. Chemical Geology, 16, 207-219. https://doi.org/10.1016/0009-2541(75)90029-7

[77] Chappell, B.W. and White, A.J.R. (1992) I and S-Type Granites in the Lachlan Fold Belt. Transactions of the Royal Society of Edinburgh Earth Sciences, 83, 1-26. https://doi.org/10.1130/SPE272-p1

[78] Mckeough, M.A., Lentz, D.R., Mcfarlane, C.R. and Brown, J. (2013) Geology and Evolution of Pegmatite-Hosted U-Th \pm REE-Y-Nb Mineralization, Kulyk, Eagle, and Karin Lakes Region, Wollaston Domain, Northern Saskatchewan, Canada: Examples of the Dual Role of Extreme Fractionation and Hybridization Processes. Journal of Geosciences, 58, 321-346. https://doi.org/10.3190/igeosci.153

[79] Watson, E.B. and Harrison, T.M. (1983) Zircon Saturation Revisited: Temperature and Composition Effects in a Variety of Crustal Magma Types. Earth and Planetary Science Letters, 64, 295-304. https://doi.org/10.1016/0012-821X(83)90211-X

[80] Ross, P.S. and Bédard, J.H. (2009) Magmatic Affinity of Modern and Ancient Subalkaline Volcanic Rocks Determined from Trace-Element Discriminant Diagrams. Canadian Journal of Earth Sciences, 46, 823-839. https://doi.org/10.1139/E09-054

[81] Harris, N.B.W., Pearce, J.A. and Tindle, A.G. (1986) Geochemical Characteristics of Collision-Zone Magmatism. Geological Society, London, Special Publications, 19, 67-81. https://doi.org/10.1144/GSL.SP.1986.019.01.04

[82] Sun, S.S. and McDonough, W.F. (1989) Chemical and Isotopic Systematics of Oceanic Basalts: Implication for the Mantle Composition and Process. Geological Society London Special Publications, 42, 313-345. https://doi.org/10.1144/GSL.SP.1989.042.01.19

[83] Deer, W.A., Howie, A. and Zussman, J. (1982) Rock Forming Minerals. Longman, London, 919.

[84] Wedepohl, K.H. (1995) The Composition of the Continental Crust. Geochimica et Cosmochimica Acta, 59, 1217-1232. https://doi.org/10.1016/0016-7037(95)00038-2

[85] Foley, S.F. and Wheller, G.E. (1990) Parallels in the Origin of the Geochemical Signatures of Island Arc Volcanic and Continental Potassic Igneous Rocks: The Role of Residual Titanites. Chemical Geology, 85, 1-18. https://doi.org/10.1016/0009-2541(90)90120-V

[86] Wilson, M. (2007) Igneous Petrogenesis. Unwin Hyman, London, 461 p.

[87] Peccerillo, A. and Taylor, S.R. (1976) Geochemistry of Eocene Calc-Alkaline Rocks from Kastamonu Area, Northern Turkey. Contributions to Mineralogy and Petrology, 58, 63-81. https://doi.org/10.1007/BF00384745 